\title{
العلاقة بين المجاز والتأويل
}

د. نورا معوض عباس معوض

المقدمة

قضـية المجـاز مـن أهـم القضـايا الفكريـة والأدبيـة التي دخلت

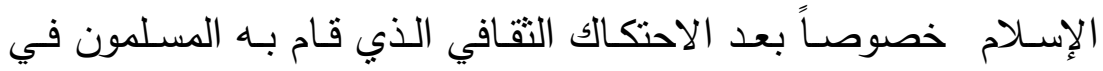
مواجهة الأفكار والمعتقدات التي وجدوا أنفسهم أمام معطياتها وتداعياتها

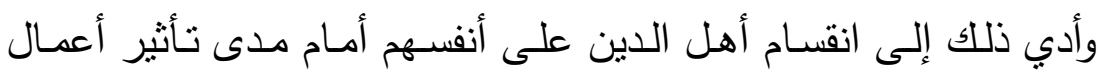

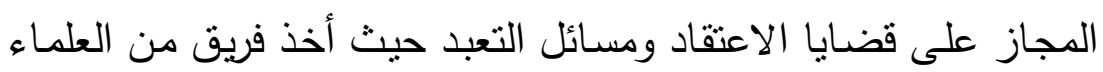
يطبقون المجاز على النصوص الثرعية وجد أهل العقيدة أنفسهم أمسام

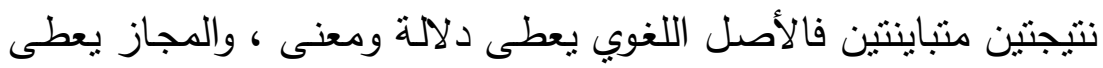

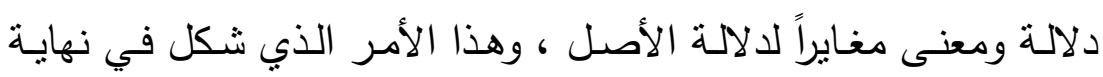

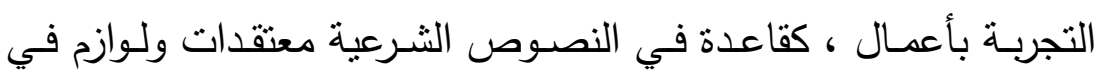

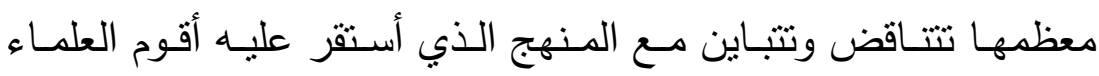

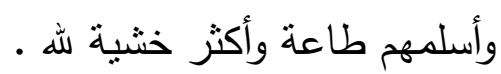

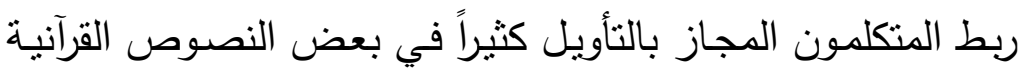

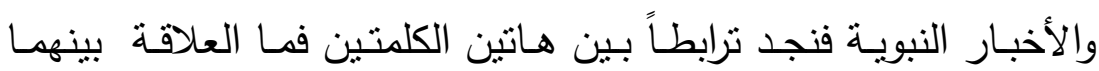

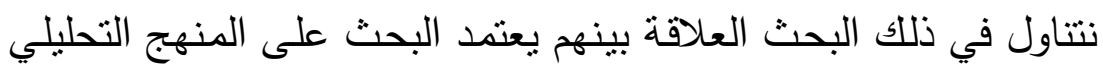

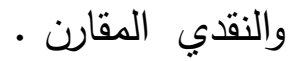

تناولت بعض النقاط الأساسية - مفهوم المجاز والتأويل لغوياً واصطلاحاً - مفهوم المجاز والتأويل عند المتكلمين ( المعتزلة والأشاعرة ) - مفهوم المجاز والتأويل في الإسلام •

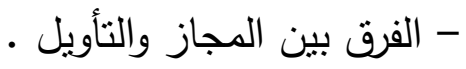
* مدرس "بقسم الفلسفة" - كلية الآداب - جامعة بنها 


\section{المجاز لغوياً}

يقول ابن فارس ت(90 9ه) فى ( معجم مقاييس اللغة )

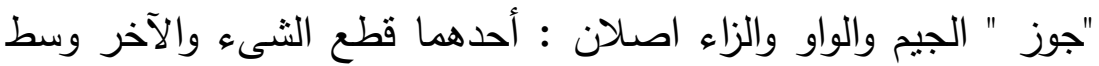

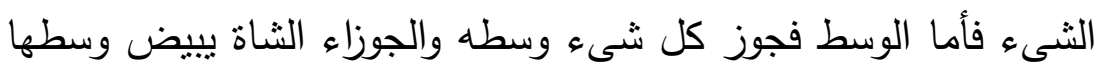

والجوزاء : نجم قال قوم سميت به لأنها جوز السماء أى وسطها . والأصل الآخر : جزت الموضع سرت فيه .

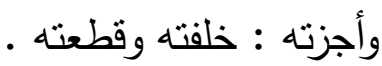
وأجزته : نفذته : واجنه : والجواز : الماء الذي يسقاه المال من الماشية والحرث

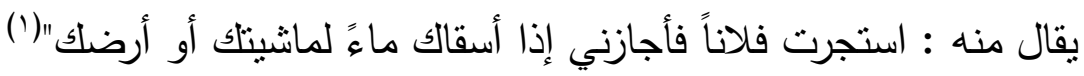
يقول الجوهري ت(ب و سهـ) في الصحاح جزت الموضع أجوزه جوازاً سلكته وسرت وفيه وأجزته الموضع أجوزه جوازاً سلكته وسرت فيه وأجزته خلقته وقطعته ، أي تركته وجاوزت الثىء إلى غيره وتجاوزته بمعنى : أب جزته وتجاوز الله عنا وعنه أي عفا . وجن

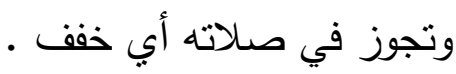

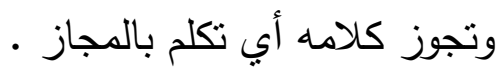
وقولهم جعل فلان ذلك الأمر مجازا إلى حاجته أي طريقاً ومسلكاً .

$$
\begin{aligned}
& \text { وتقول اللهم تجوز عني وتجاوز عنى بمعنى (') . }
\end{aligned}
$$

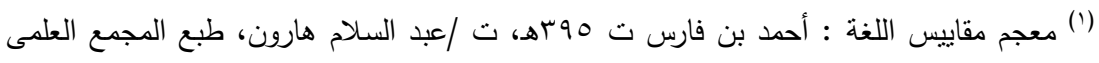

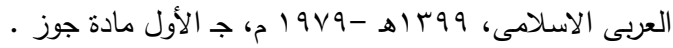


- الخلاصة أن المجاز اللغوي هو ما جاز مكانه الأصلي وتعداه إلى غيره . وانه يدل على الانتقال والتحول من وضع إلى آخر على اختلاف في

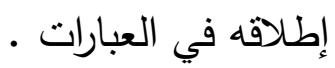
-المجاز اصطلاحاً المجاز " ما أفيد به معنى مصطلح عليه ، غير ما أصطلح عليه فى المى

أصل تلك المواضع التي وقع التخاطب بها لعلاقة بينه وبين الأول "(r). يقول ابن تيمية ( شيخ الإسلام المتوفى ولى لهـ ) " الحقيقة هي اللفظ

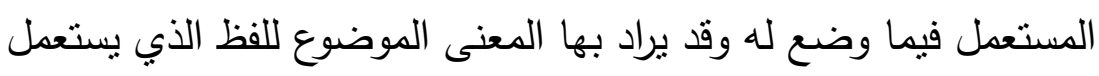
اللفظ فيه فالحقيقة أو المجاز هي عوارض الألفاد بهاظ في في اصطلاح أهل الأصول ، وقد يجعلونه من عوارض المعاني لكن الأول أشهر "(").

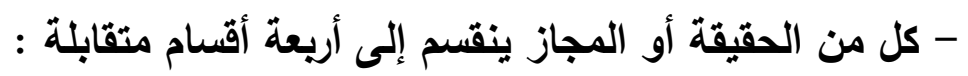

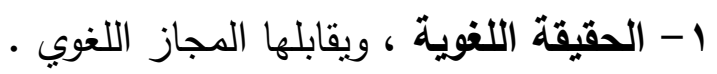

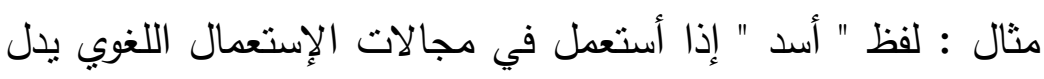
على حيوان مفترس فهو حقيقة لغوية .

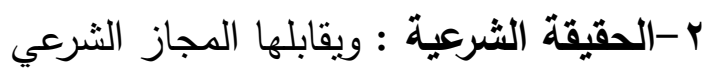
إذا أستعمل اللفظ في مجالات استعمال الألفاظ الثرعية بمعناه

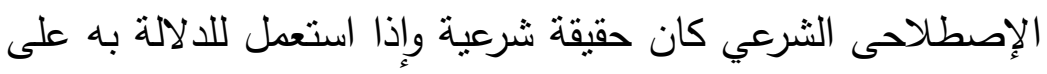
معنى آخر ولو كان معناه اللغوي الأصلي كان بالنسبة إلى المفهوم الإصطلاحى الثرعي كان مجازاً شرعياً.

(1) تاج اللغة وصحاح العربية:الأمام ابونصراسماعيل الجوهري، ت/ أحمد عبد الغفورعا، دار العلم

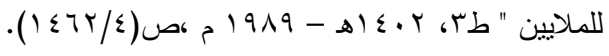

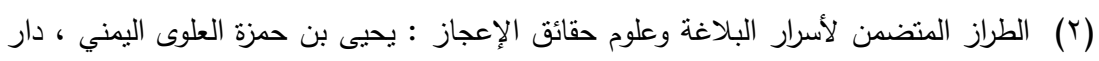

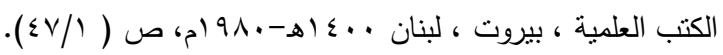

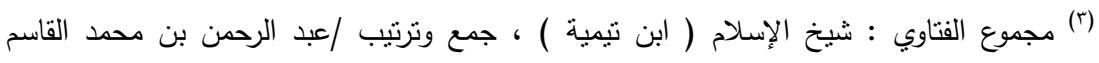

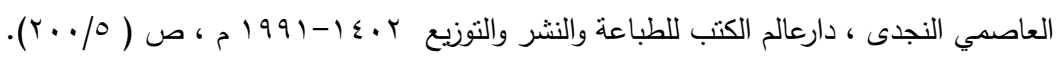


مثال لفظ " الصلاة " : إذا أستععل في مجالات الدراسة الثرعية للدلالة به على الركن الثاني من أركان الإسلام فهو حقيقة شرعية . r- العقيقة في العرف العام : ويقابلها المجاز في العرف العام ويراد الاده بالعرف العام ما هو جاز على السنة الناس في عرف عام على خلاف

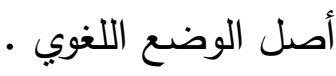
إذا أستعمل اللفظ في مجالات العرف العام بمعناه الذي جرى عليه هذا العرف كان حقيقة عرفية عامة وإذا أستعمل للالالة به على معنى آخر ولو كان معناه اللغوي الأصلي كان بالنسبة إلى هذا العرف مجازاً عرفياً

مثال : لفظ الدابة : جرى إطلاقه في العرف العام على ما يمضى من الحيوانات على أربع فإطلاق هذا اللفظ ضمن العرف العام بهذا المعنى حقيقة عرفية عامة . عامة ع - الحقيقة فى العرف الخاص: ويقابلها المجاز فى العرف الخاص يراد بالعرف الخاص مصطلحات العلوم ، إذ لكل علم مصطلحاته من الكلمات اللغوية ذات الدلالات اللغوية . مثال : ألفاظ " الجمع - الطرح - الضرب - التقسيم ونحوها " فى دلى دان الرياضيات فإذا استعملت هذه الألفاظ ضمن علومها على وفق مفاهيمها الإصطلاحية كانت حقيقية في العرف الخاص ، وإذا أستعملت في

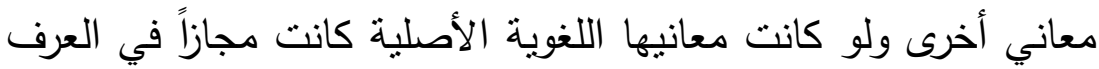
(الخاص (') (1) - من خلال ما سبق نجد أن الحقيقة : هي الأصل وهى الباقية على

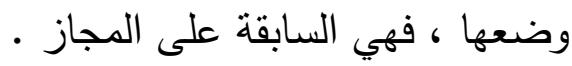
والمجاز منقول عن وضعه إلى وضع آخر آلى - أبي في غير موضعه . 
"التأويل لغوياً:

التأويل : مصدر من باب التفعيل وله في اللغة معنيان • لألهابل

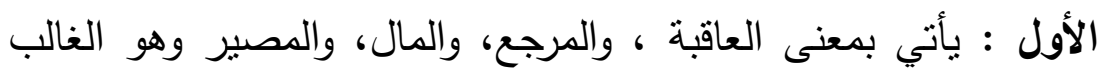

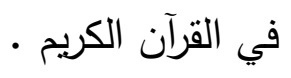

والثثاني : ويأتي بمعنى التفسير ، والبيان، والتذبر ، وهو الغالب في أقوال

$$
\text { السلف : البالف }
$$

$$
\text { ومما يدل على المعنى الأول }
$$

قال ابن منظور في ( لسان العرب ) : الأول : الرجوع ، آل الثىء الاول

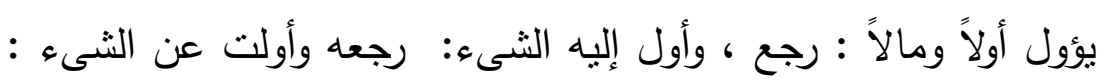

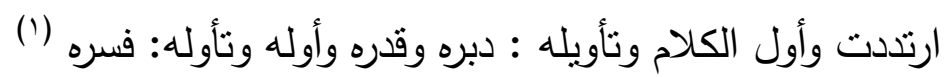

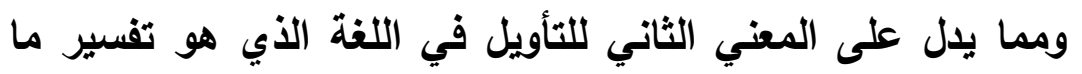

- قول أبو عبيدة : " التأويل في كلام العرب التفسير "(؟) -ابن جرير في تفسيره عن كل آيـة : " القول في تأويله قوله - ثمبرد

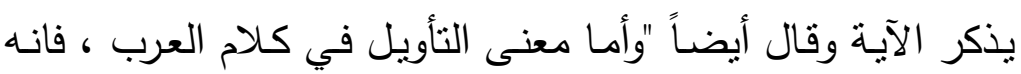
التفسير ، والمرجع ، والمصير (r) .

التأويل اصطلاحياً

(1) لسان العرب : ابن منظور جمال الدين محمد بن مكرم بن على الانصارى ، دار الصادر ، بيروت

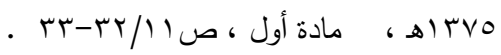

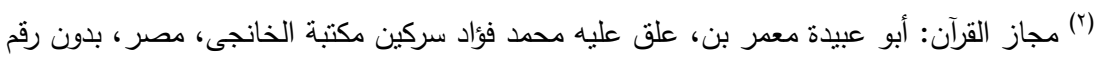

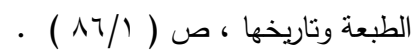

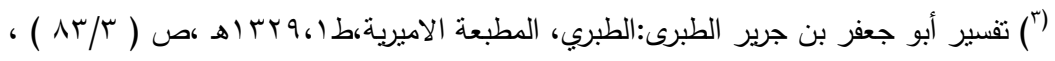


ذكر ابن القيم في مختصر الصواعق بيان حقيقة التأويل لغة وإصطلاحاً

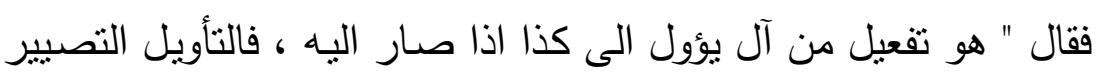

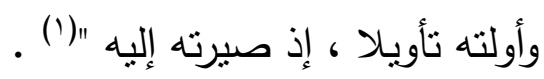

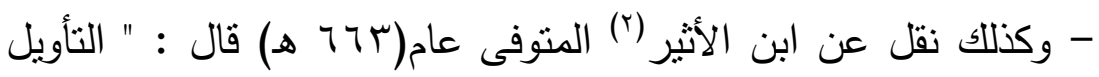

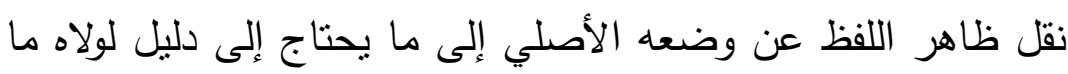

ترك ظاهر اللفظ "(").

" : أيضاً ينقل لنا الزبيرى() في تاج العروس عن ابن الكمال(ه) إذا يقول قال ابن الكمال :" التأويل صرف الآية عن معناها إلى معنى تحتمله ،

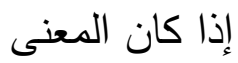
المحتمل الذي تصرف إليه الآية موافقاً للكتاب والسنة " الدماني

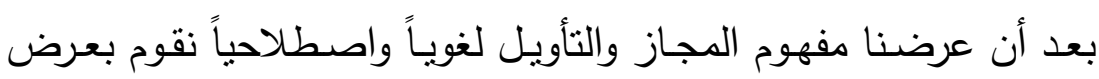

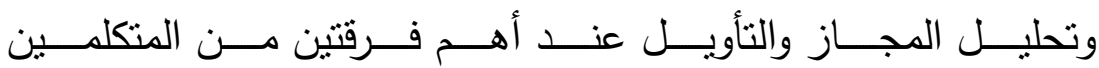

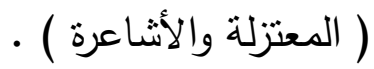

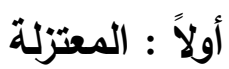

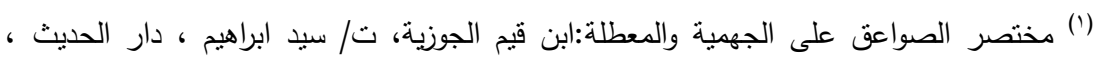

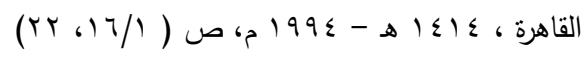

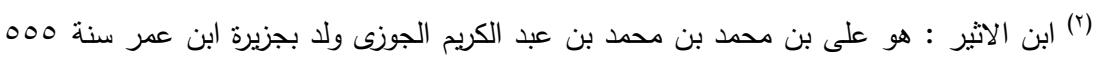

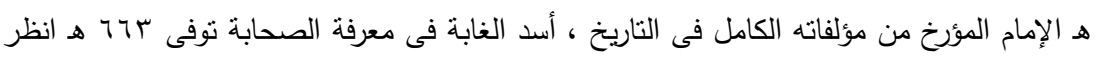

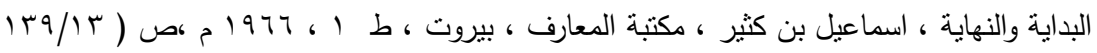

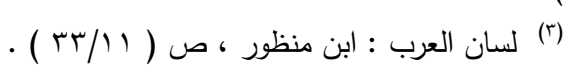

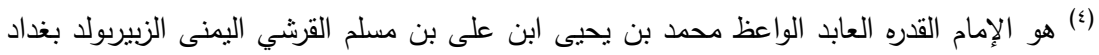

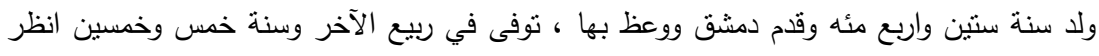

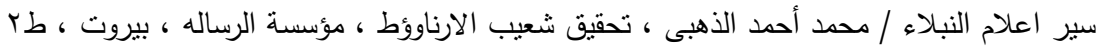

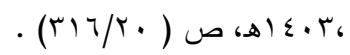

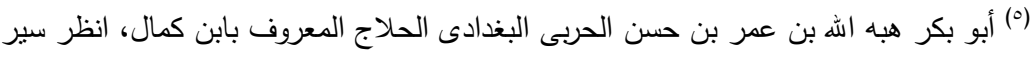

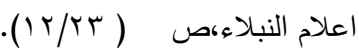


- يعتبر المعتزلة هم أول من فتح الباب أمام بدعة المجاز ، وذلك من

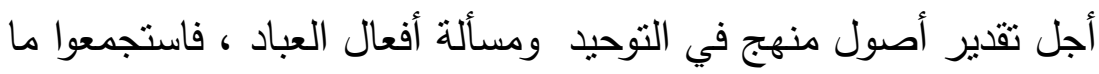
لديهم من شبه وأقوال من أجل تقدير إثبات المجاز وأنه قسيم الحقيقة ثابت في الوضع ، واستغلوا جميع وسعهم في نشر هذه المقالة بين الناس

" فالمعتزلة هم الذين حملوا الآيات على المجاز بتأويلها حيث تأولوا

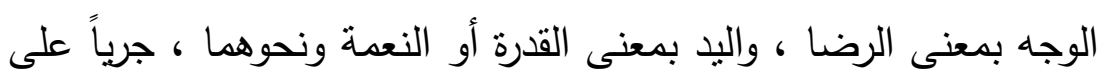

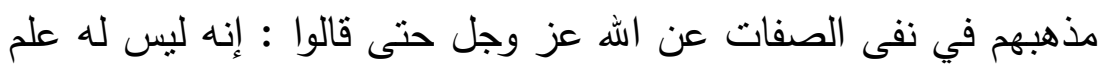

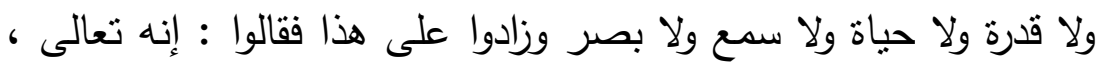

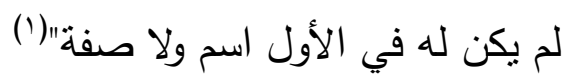
إن المعتزلة بعد أن حملت النصوص لاولم ولا هلى المجاز ، أخذت ما رأته

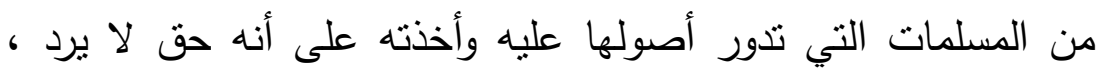
وذلك كما هو ملاحظ فى كتبهم باعتبار ما حملوه على المجاز انه هو

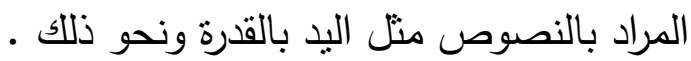

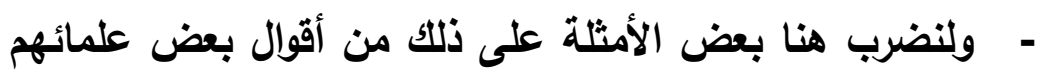

$$
\text { مثال ذلك : }
$$

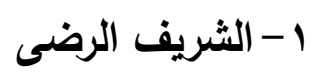

صاحب كتاب المجازات النبوية، وتلخيص البيان ، والذي كان شيعى المذهب ولكنه تتلمذ على بد ابن جنى المعتزلى،وتأثز به تأثراً بالغاً

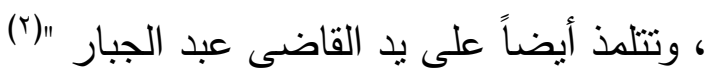
قال الرضى في قوله "صلى الله عليه وسلم": " هذا جبل يحبنا ونحبه " :

(1) الفرق بين الفرق :عبد القاهر بن طاهر البذادى ، تـ/دمحمد محى الدين عبد الحميد دار ، برد

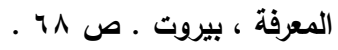

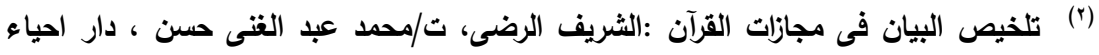

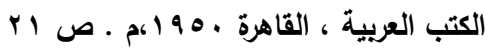


"وهذا القول محمول على المجاز ، لأن الجبل لا يصح أنُ يحَب ولا "يُحِب "

ثم قال في تأويل الحديث : فالمراد إذا أن أحداً جبل بحبنا أهله، ونحب

أهله ، وأهله هم أهل المدينة من الأنصار أوسهم وخزرجهم"(') وقال عن حديث " قلب ابن آدم بين أصبعين من أصابع الرحمن " "إن كان نقله صحيحاً فله وجه فى كلام العرب يسوغ حمله عليه، ورده إلبه بما يوافق صفات الله الذي لا يشبه الخلق التي خلقها ، والبرايا التي براها وصورها وهو أن الإصبع فى كلام العرب اسم للأثز الحسن الذي تظهر سمته وتشتهر علاقته "(r) . ثم أول الحديث بقوله :" ما من آدمى إلا وقلبه من الله بين نعمنين حسنتين أحداهما : ما من به عليه من معرفة خالقه ورازقه ،

والأخرى : الغبطة بما انعم به عليه من تحسين خلقه وتوسيع رزقه "(r) ثم قال :" أما ما تذهب إليه المشبهة من أن الإصبع ها هنا على حقيقتها

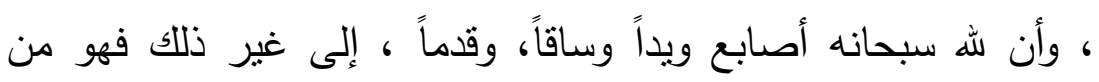
الجهالات التى تدفعها العقول بأوائلها، وتقضى بفسادها قبل إعمال النظر فيها ، وكيف يصح هذا القول لهم ويقوم في عقولهم مع اعتقادهم أن الله سبحانه مستو على العرش كاستواء القاعد فى مقعده ،الممهد على مهاده، وأن بينه وبين المخلوقين من بنى آدم سبع سموات، وما بين كل سماء وسماء مسيرة خمسمائة عام ، وسمك كل سماء منل ذللك

(1) المجازات النبوية : الثريف الرضى ت/ طه عبد الرؤوف سعد ، مطبعة الحلبي ، القاهرة اجه اهـ، 
فكيف يسوغ أن تكون أصابعه .... وأصله إلى قلوب خلقه دع هذا البعد

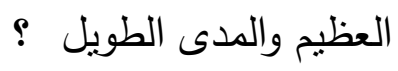

ولو كان ذلك على حقيقته لوجب أن يكون لله من الأصابع ما لا نهاية له له

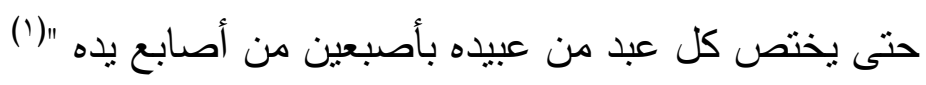

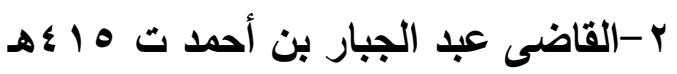
وأما القاضى عبد الجبار المعتزلى المنهج فقد أكثر من التأويل

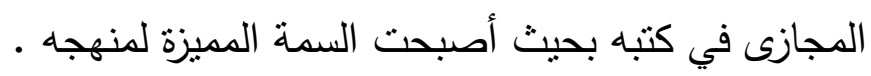
مثال ذلك تأويله لقوله تعالى :" وجاء ربك بحك والملك صفاً صفاً "

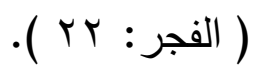
قال " إنه تعالى غيره، جرياً على عادتهم في حذف المضاف وإقامه

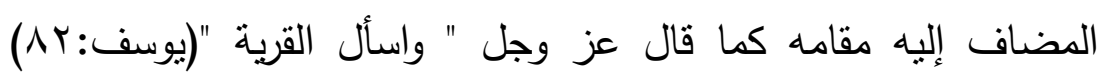

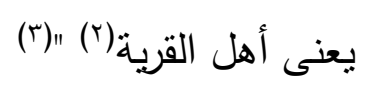

كما نجده مثناً فى الآيات التي فيها نسبة الاستهزاء كقوله تعالى " اله له يستهزى بهم ويمدهم فى طغيانهم يعمهون " (البقرة 10 ).

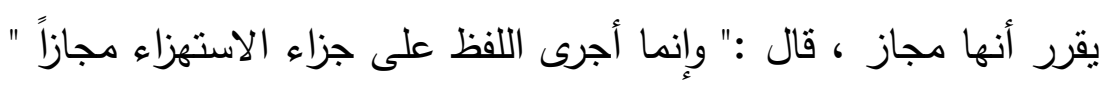

ومع كثرة صرف النصوص عن ظاهرها عند القاضى عبد الجبار وحملها على المجاز إلا أنه في أحد كتبه يقول ما يخالف فعله حيث صرة صرح بأن

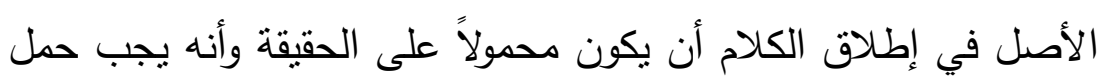

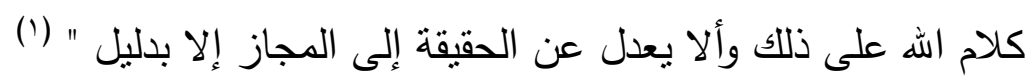

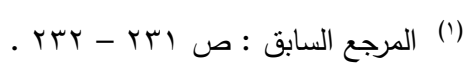

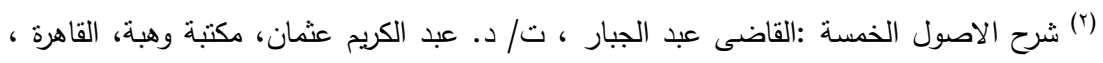

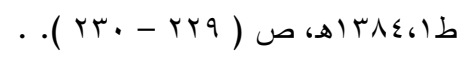

(ץ) تنزيه القرآن عن المطاعن: القاضى عبد الجبار، الثركة الثرقية للنشر والتوزيع، دار النهضة

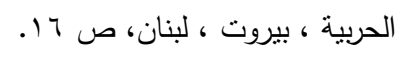

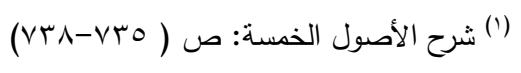


إلا أنه كما تقدم من أمثلة يحمل كلام الله على المجاز بدون دليل إلا

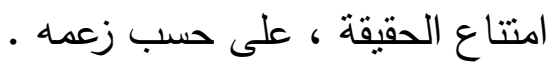

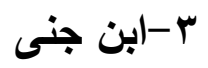

هذا الرجل وشيخه : أبوعلي من كبار أهل البدع والاعتزال

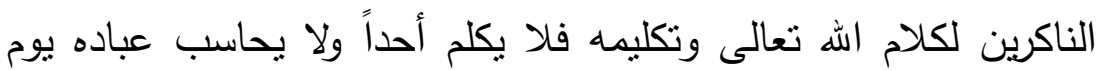

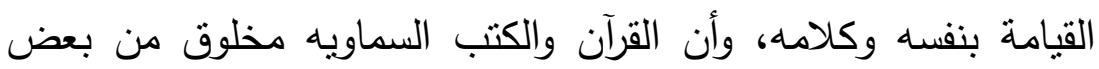
مخلوقاته ، وليس له صفة تقوم به فلا علم به عندهم ولا قدرة ولا حياة ولا

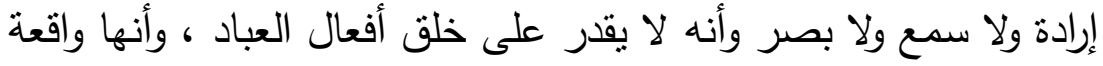

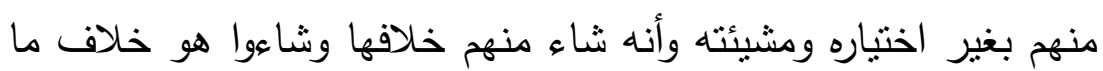

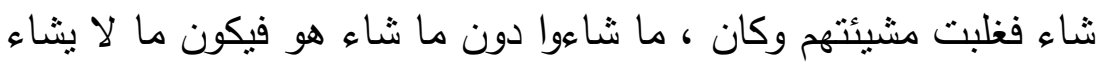

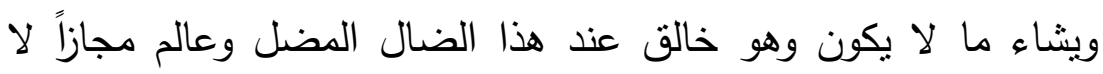

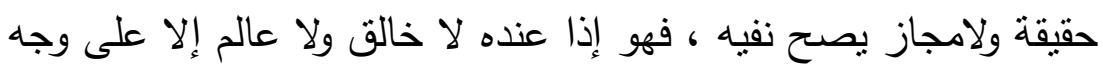

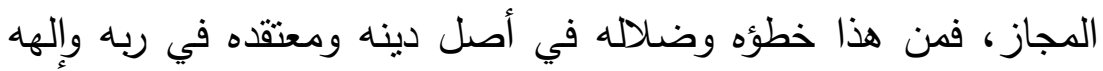
مما الظن بخطئه وضلاله فى ألفاظ القرآن ولغة العرب .

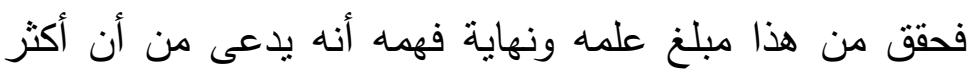

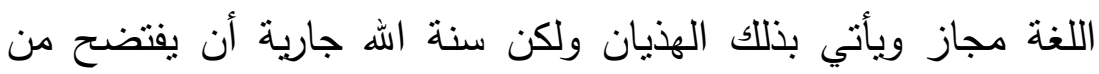
أستهزأ بحزبه وجنده، وكان الرجل وشيخه فى زمن قوة شوكة المعتزلة وكانت الدولة دولة نقض واعتزال وكان السلطان عضد الدولة ابن بويه ونه ونه وله صنف أبو على الإيضاح وكان الوزير إسماعيل بن عباد معتزلياً

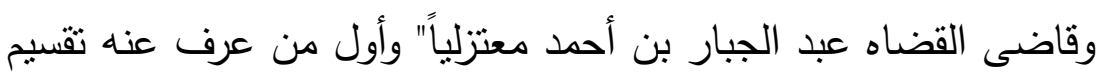
الكلام إلى حقيقة ومجاز المعتزلة والجهمية "(1) فهو على مذهب المعتزلة ويرى رأيهم يقول في كتابه الخصائص "

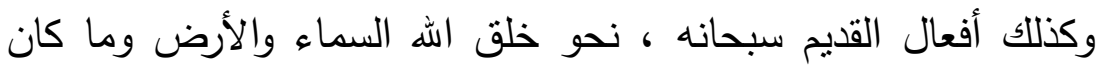


مثله، ألا ثرى - أنه عز اسمه - لم يكن منه بذلك خلق أفعالنا ولو كان

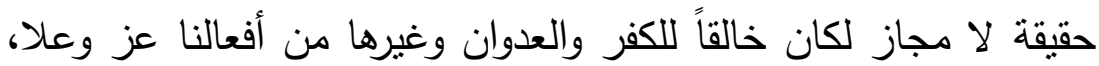

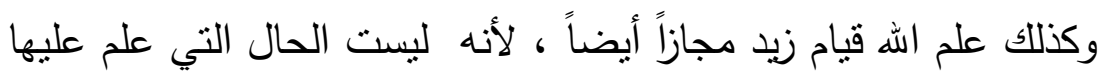
قيام زيد هي الحال التي علم عليها قعود عمرو ، ولسنا نثبت له سبحانه

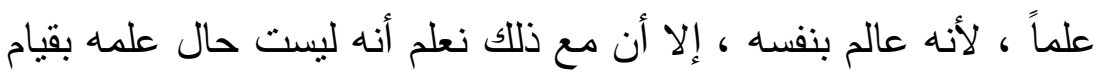

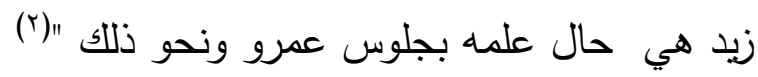
"ومما يؤنس باعتزاله أنه ....... يكرر عبارة " المنزلة بين منزلتين "

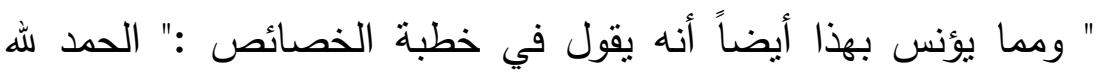

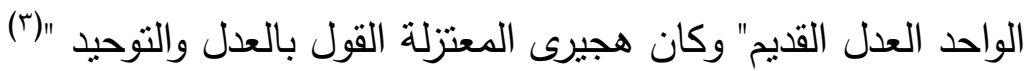
وفى المقريزي() " المعتزلة الغلاة في نفى الصفات الإلهية ، القائلون بالعدل والتوحيد " ويقول الزمخشرى فى خطبة الكثاف:" ولقد رأيت إخواننا في الدين من أفاضل الفئة الناجية العدلية " وهو يعنى المعتزلة ويقول بعد هذا :" فأبوا إلا المواجهة والإستشفاع بعظماء الدين وعلماء

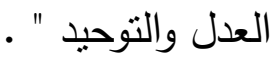
ويقول السيد الثريف فى كتابته على هذا الموطن من الكثاف :" والمعتزلة سموا أنفسهم أهل العدل لأنهم أوجبوا على اله تعالى ما هو هن

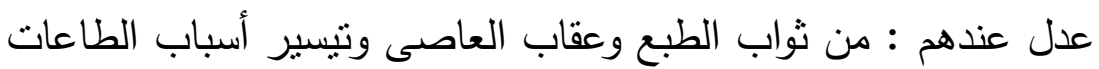

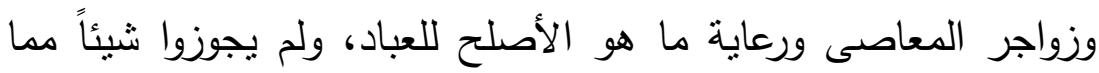

$$
\begin{aligned}
& \text { (r) الخصائص : أبى الفتح عثمان بن جنى ، ت / محمد على النجار ، الناثر دار الكتاب العربي، }
\end{aligned}
$$

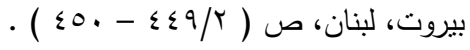

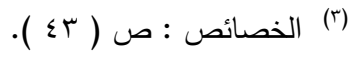

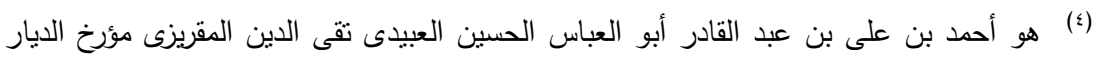

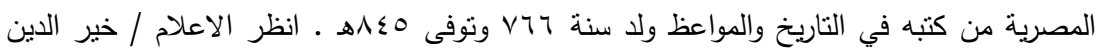

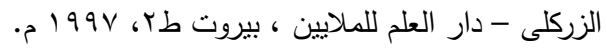

$$
\begin{aligned}
& \text { r. }
\end{aligned}
$$


يعد ظلماً ن وأهل التوحيد اذ لم يثبتوا له تعالى صفات قديمة زائدة على

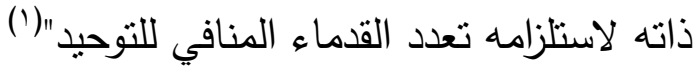
وابن جنى ممن أسرف وبالغ في إدعاء المجاز حيث أدعى أن أكثر

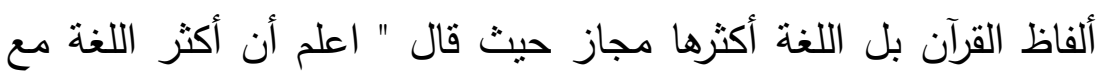

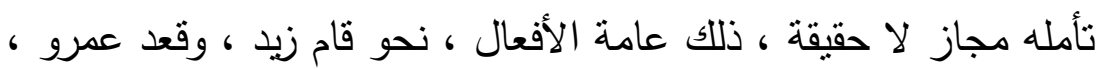

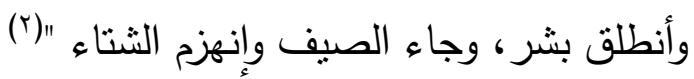
وقد تقدم معنا إعماله للهجاز في أفعال الله سبحانه حتى عد أن خلق الله

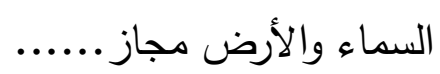
وعد من توكيد المجاز قوله تعالى " وكلم اله موسى تكليماً

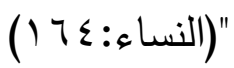
كما عد من توكيد المجاز مما يرى إنه قد حذفت صفة قول الله تعالى "

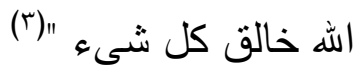
قال " وأما قوله سبحانه " وفوق كل ذبي علم عليم "(يوسف:V7)

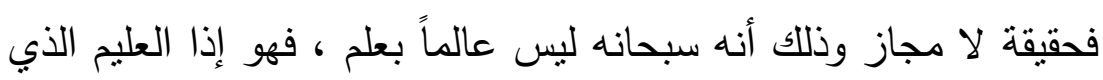
فوق ذوى العلوم أجمعين ولذلك لم يقل : وفوق كل عالم عليم ، لأنه -

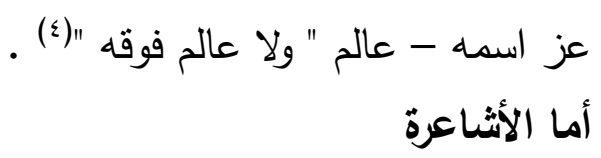

سميت بهذا الاسم نسبة إلى أبى الحسن الأثعرى، على بن إسماعيل بن

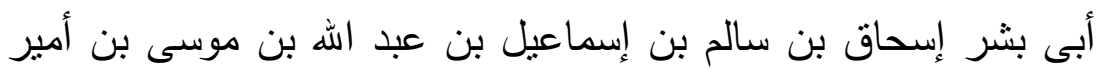

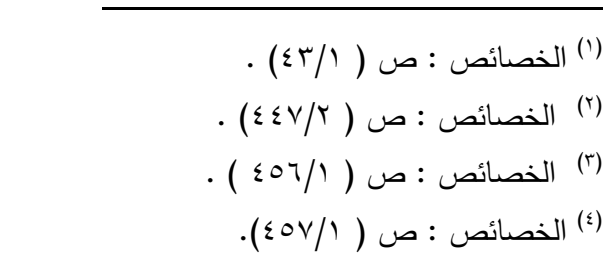


البصرة بلال بن أبى برده بن أبى موسى عبد الله بن قيس بن حضار

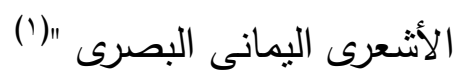
والأشعرى يعد شيخ الأشاعرة عند الإطلاق، وقد مر الأشعرى بثلاث

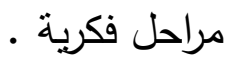
الأولي: التي كان فيها معتزلياً فلهذا قد أخذ بأصولهم حتى رسى فى

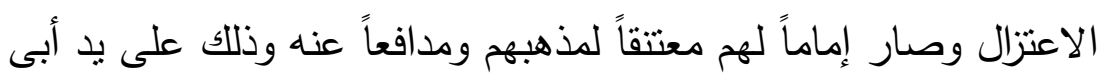
على الجبائى، إلى أن بلغ سن الأربعين ثم دارت بينه وبين الجبائى

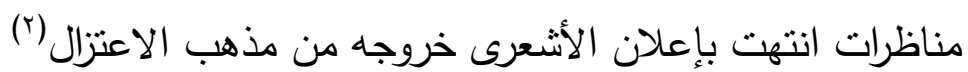
الثانية : التي خرج فيها عن مذهب الاعتزال ومال إلى أهل السنة ولكنه

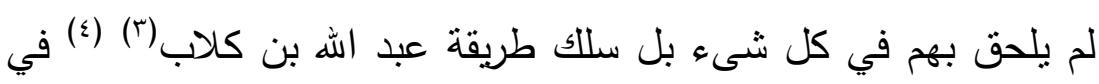
إثبات الصفات اللازمة التي تقوم بذات الله ونفى الصفات لهات الاختيارية

عنه

وفى هذه المرحلة اثبت الصفات العقلية السبعة : وهى الحياة ، والعلم ، والقدرة ، الإرادة، والسمع ،والبصر ، والكلام ، وتأويل الخبرية

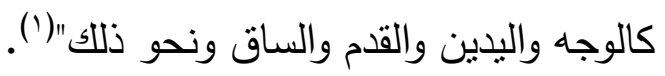

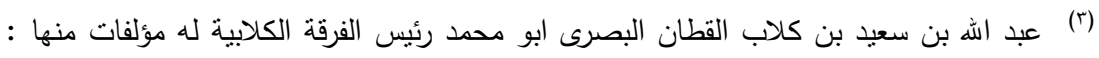

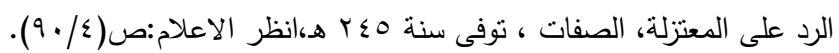

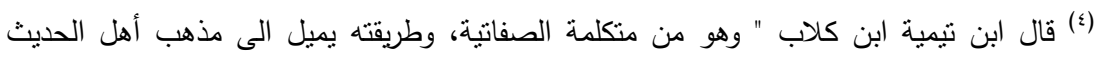

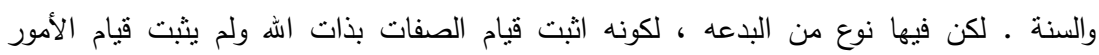

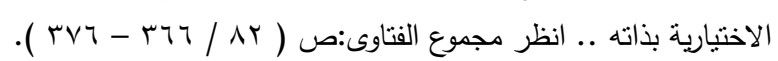

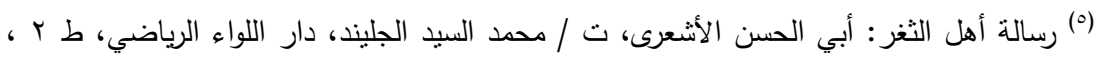

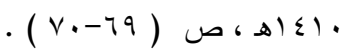

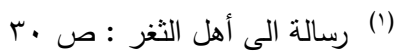


المرحلة الثالثة : التي انتقل فيها عن طريقة ابن كلاب ، والرجوع التام الى مذهب أهل السنة والجماعة، وأعلن أنه على مذهبهر ومتبع لما قالوه

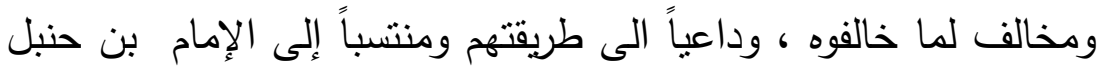

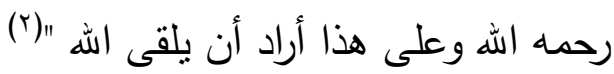
يقول أبو الحسن فى كتابه الإبانة " فإن قال لنا قائل : قد أنكرتم قول المعتزله والقدرية والجهية والحرورية والرافضة والمرجئة فعرفونا قولكم الذي تقولون وديانتكم التي تدينون قيل قولنا الذي نقول به وديانتتا التي ولي وليه ندين بها : التمسك بكتاب ربنا عز وجل ، وبسنة نبينا صلى الله عليه

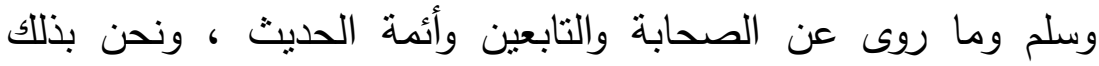

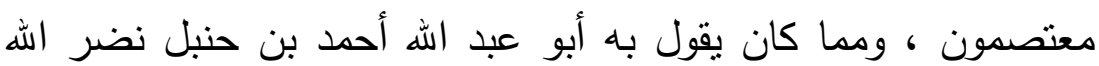

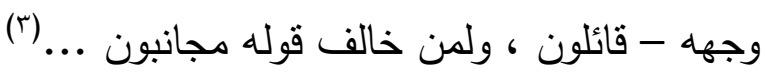
مفهوم التأويل عند الإمام الجوينى ولمن هانه

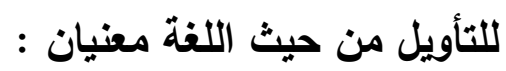
المعنى الأول : الحقيقة التي يؤول الكلام إليها ، وهى الحقيل الحقيقة الموجودة في الخارج ، فتأويل ما أخبر الله به في الجنة من مأكل التل ومشرب وما أخبر به من قيام الساعة وأحوال يوم القيامة هي الحقائق الموجودة أنفسها لا ما يتصور من معانيها في الأذهان.

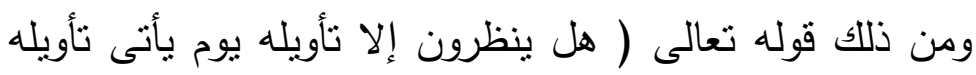
يقول الذين نسوه من قبل قد جاءت رسل ربنا بالحق ) ). ( الاعراف : ror ) وقوله تعالى : ( فإن تتازعتم في شىء فردوه إلى الله

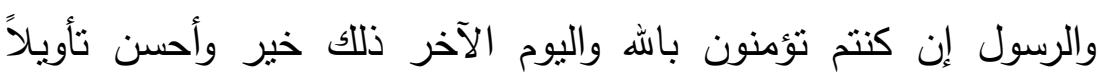

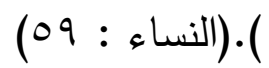

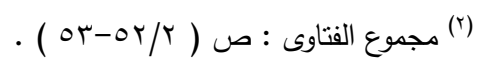

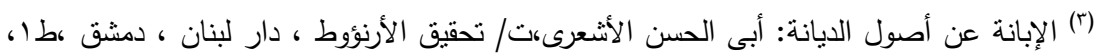

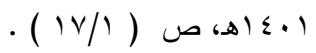
$\Gamma \cdot \wedge$ 
وقوله تعالى على لسان يوسف عليه السلام ( يأ أبت هذا تأويل

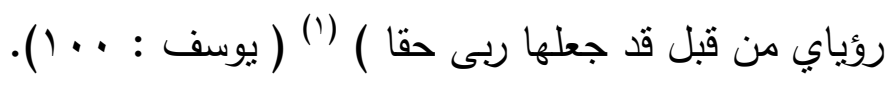

المعنى الثاني : التفسير والبيان وهذا هو اصطلاح أهل التفسير

$$
\text { والسلف من أهل الققه والحديث . }
$$

ومنه قول ابن جرير وغيره : القول في تأويل قوله تعالي كذا وكذا ،

)

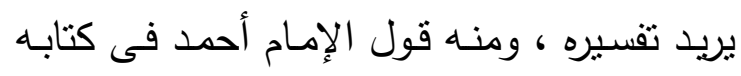

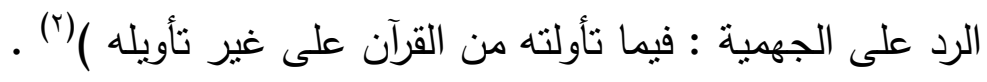
أما المعنى الثالث : للتأويل فهو المعنى الاصطلاحي وهو صرف اللفظ عن ظـاهرة المتبـادر منـه إلى محتمـل مرجوح لـليل ، وهذا هـو لهو

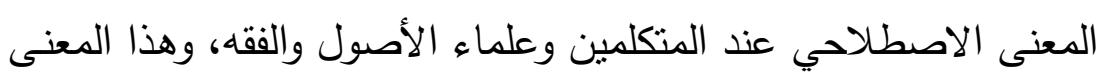
هو الذي اصطلحوا عليه ومثاله قوله ( صلى الله عليه وسلم ) " الجار الهين

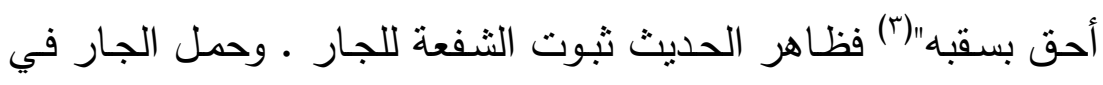
الحديث المذكور على خصوص الثـريك المقاسم محتمل مرجوح. ويعد لهد

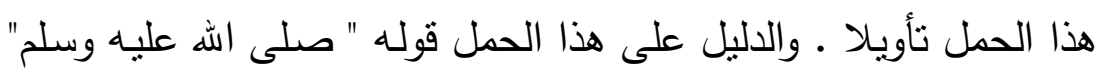

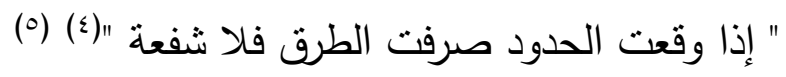
والمثال السابق يعد من قبيل التأويل الصحيح . أما تأويل المتكلمين لليد في قوله تعالى ( ما منعك أن تسجد لما خلقت

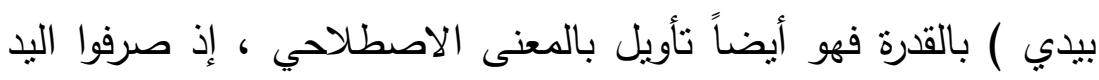

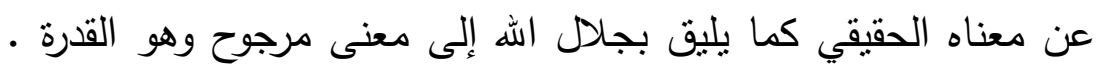

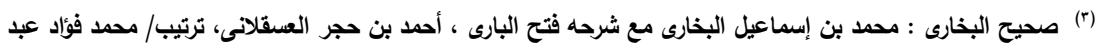

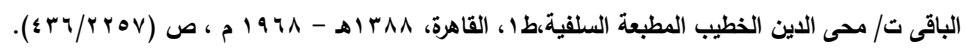

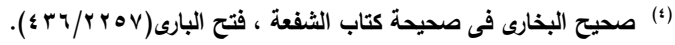

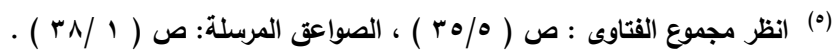


ولكن هذا التأويل يعد من قبيل التأويل الباطل فلا دليل صحياً يقتىى

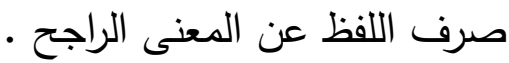
وأمام الحرمين يعنى بالتأويل مفهومه الاصطلاحي ، وهو صرف اللفظ عن معناه الراجح إلى معناه المرجوح لاليل ـ فقد ذكر ركني التأويل في بالي كتابه : الثامل وهما :

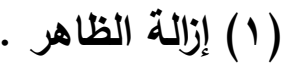

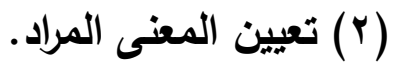

وذللك أثناء جدله مع من يأبى تأويل الاستواء ، إذ برى أمام الحرمين

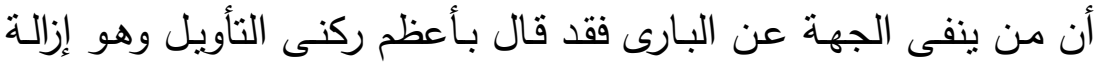

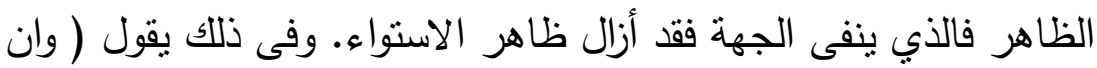
صرح هؤلاء بنفي الجهات فقد وافقونا في المذهب، وقالوا بأعظم ركني التأويل، فإن الذي يحاذره منكرو التأويل إزالة الظواهر ــ والذي نفى الجهة لنه

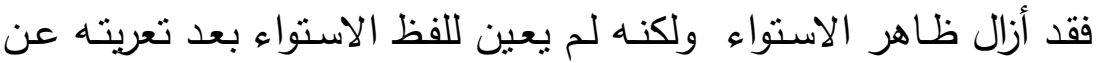

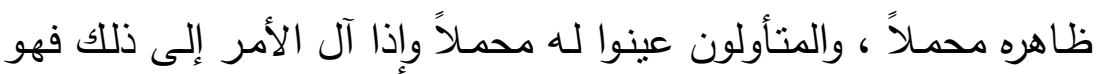

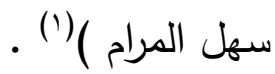
فهذا النص يتضمن ركني التأويل عند إمام الحرمين وهما : عدم

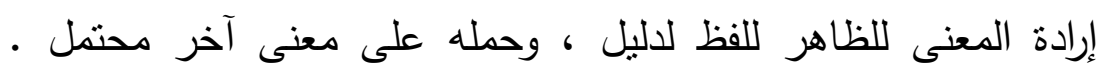

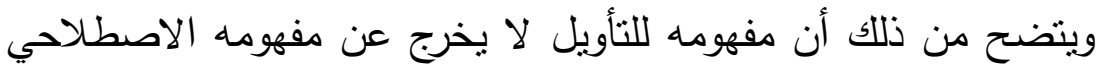

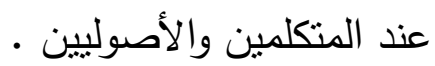


وقد عرف التأويل في كتابه البرهان بأنه : ( رد الظاهر إلى ما إليه مآله في دعوى المؤول وإنما بستعمل إذا علق بما بتلقى من الألفاظ

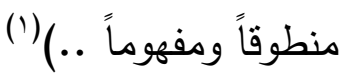
وهذا التعريف هو التعريف في اصطلاح المتأخرين . فقوله ( رد الظاهر ) بمعنى صرف اللفظ الظاهر أى المعنى الراجح

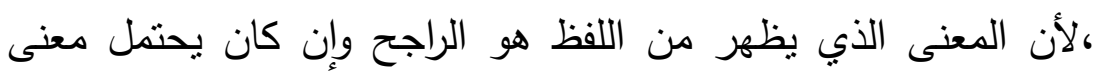

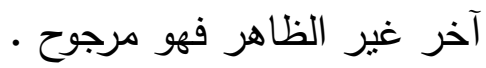
أسباب التأويل عند إمام الحرمين يعدد إمام الحرمين إلى تأويل الظواهر السمعية قرآناً أو سنة لأحد سبيين : السبب الأول : دعواه أن ظواهر الآية يتعارض مع الدليل العقلي ولهذا أول اليد فى قوله تعالى : (ما منعك أن تسجد لما خلقت بيدى) ( ص : Vo) أولها بمعنى القدرة ، والذي جعله يؤولها دعواه أن العقل

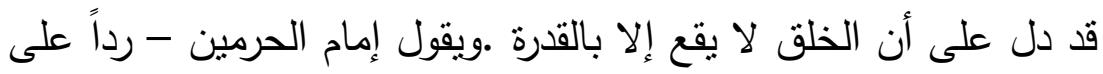

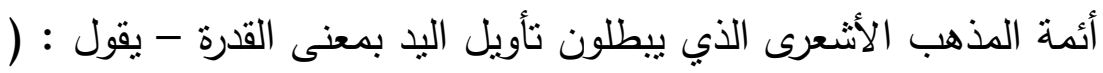

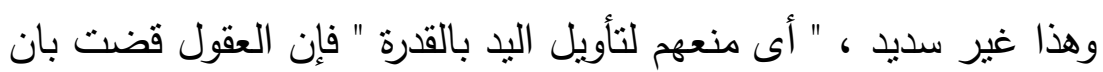

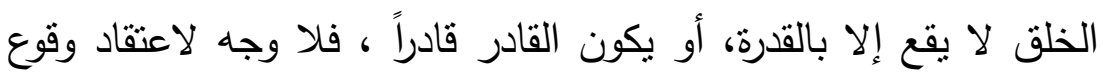

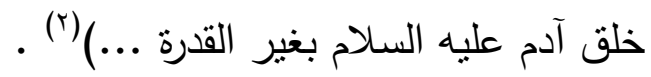
ثم يقول أيضاً : ( فالظاهر متروك إذا والعقل حاكم بأن الذي يقع

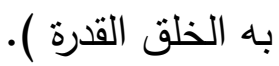

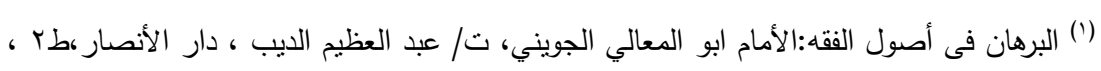

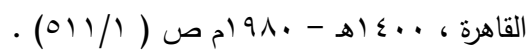

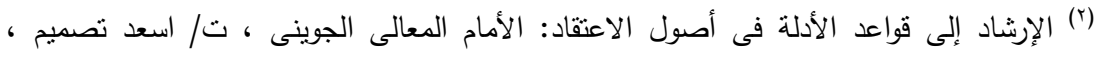

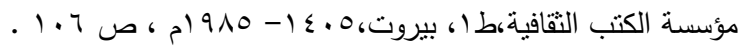


وهكذا نرى دافعه نحو تأويل الآية وصرفها عن معناها الحقيقى، هو

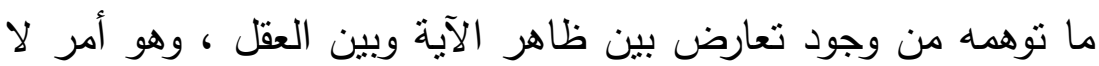
يسلم له .

أما السبب الثاني : فهو ما يراه من التعارض بين ظاهر الآية ودليل

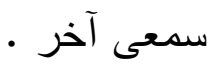

ولهذا السبب يؤول قوله تعالى(لا تدركه الأبصار وهو يدرك الأبصار)

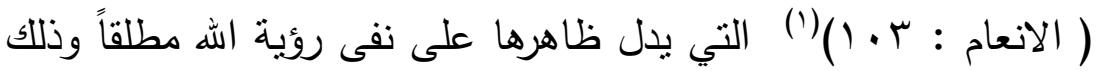
بثقييد الإطلاق فيها بأنه نفى للروية في الدنيا، وسبب ذلك الكان التأويل

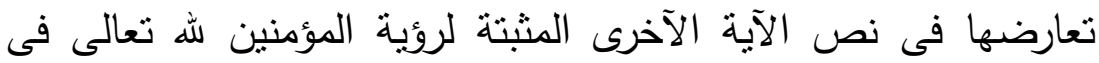

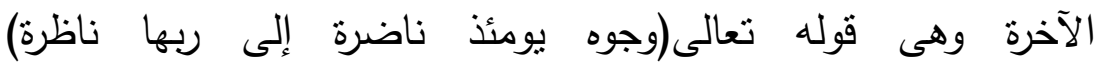

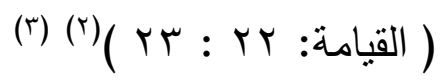

ويرى إمام الحرمين أن التأويل لظاهر النصوص جائز بضوابط معينة وشروط محدة وضعها هو طبعا. ودليله على الجواز الإجماع • يقول : ( وتأويل الظواهر على الجملة مسوغ، إذا استجمعت الشرائط ) ثم يقول : ولم ينكر أصل التأويل ذو مذهب ، وإنما الخلاف في التفاصيل ، وإن إن إنه

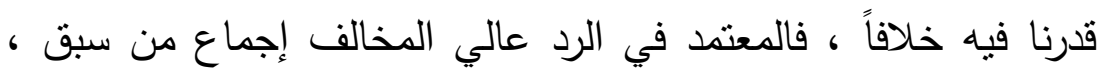

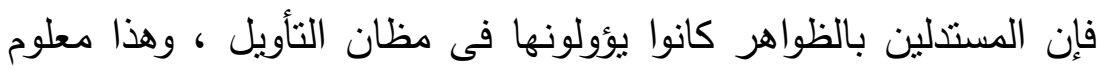

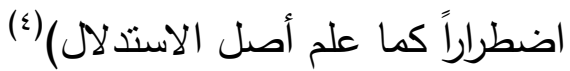

$$
\begin{aligned}
& \text { (') سورة الأنعام: r. } 1 \text { (1) }
\end{aligned}
$$

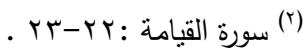

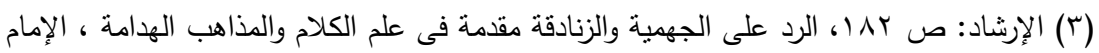

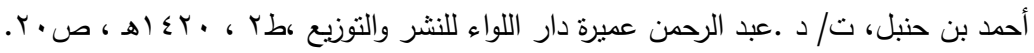

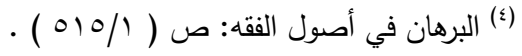


هذا حكم التأويل - في الجملة - عند إمام الحرمين ، فما حكم تأويل

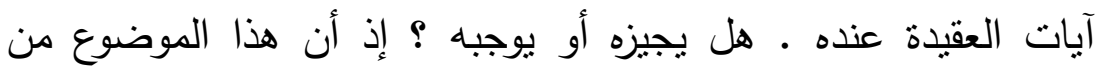

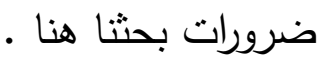

الواقع أن موقف إمام الحرمين من تأويل آيات العقيدة وحكمه عليه لم يكن واحداً في كتابيه : الإرشاد والثامل ، إذا أن موقفه من تأويل

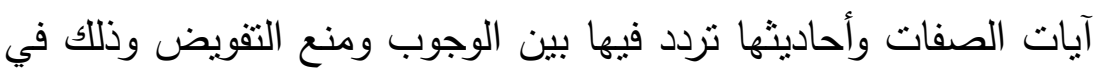
كتاب الإرشاد ، وجواز التفويض في ترجيح التأويل في كتاب الثامل .

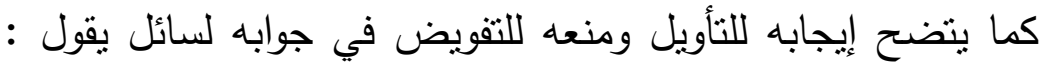

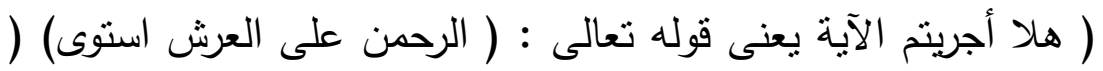

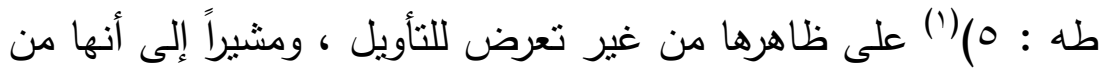

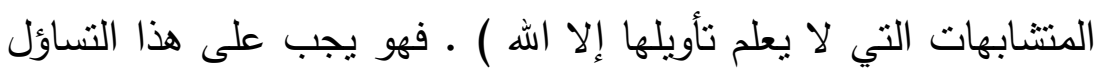

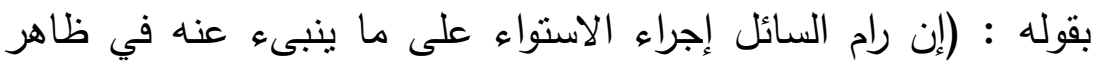

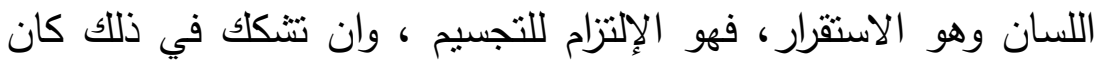

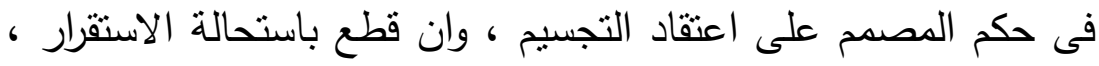
فقد زال الظاهر والذي دعا إليه من إجراء الآية على ظاهرها لم يستقيم له أله

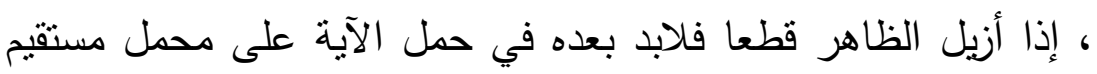

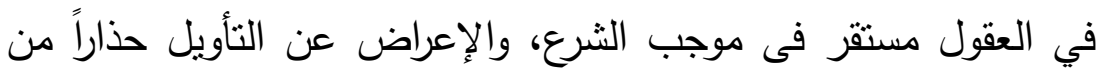
مواقعة محذور في الاعتقاد يجر إلى اللبس والإبهام ، واستزلال العوام، وتطريق الثبهات إلى أصول الدين ، وتعريض بعض كتاب الله تعالى الهى اللى

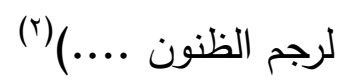

وفى ضوء هذا النص يتضح التأويل ويراه حتما، كما أنه يمنع للتقويض إذا لا بد من تحديد معنى للآية بما بتفق مع العقل. 
أما في الثـامل فقد أجاز التفويض وذكر أنه مسلك لبعض الأئمة

وأنه مذهب الإمام مالك رضى الله عنه .

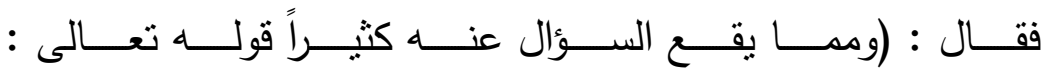

( الرحمن على العرش استوى) (طه : 0) (') وقد افترق الأئعة في وجهـ

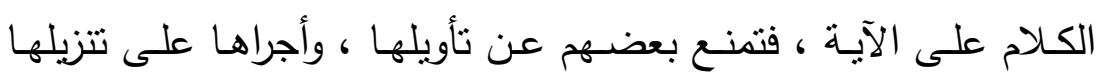
ولكن مع القطع بنفي الجهات والمحاذيات والكيفية والكمية ، وهذا القائل

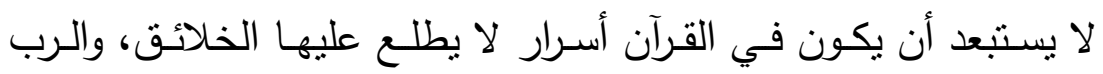

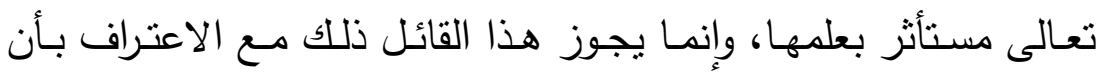
المغيب عن الخلق من المعاني المكنونة المستأثر بعلمها، لا يكون مما والها

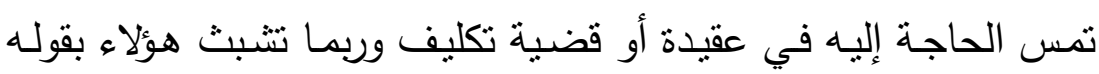

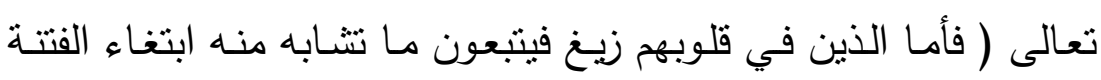

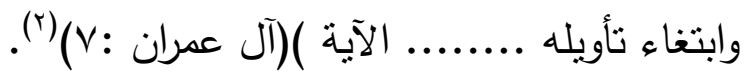

ومما نقل عنه الانكفاف عن تأويل هذه الآية ماللك رضى الله عنه، الهانه فإنه سئل عنها فقال : الاستواء معقول والكيف غير معقول والإيمان واجب والسؤال عنه بدعة . فإن سلك ساللك هذه الطريقة وكان يعتقد تقديس القديم عن مشابهة

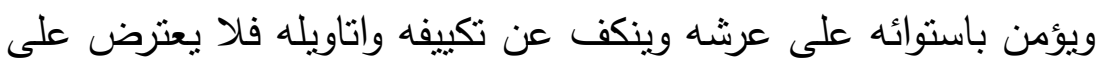
من قال ذلك بما يقطع به (r) . فقى هذا النص نلاحظ ما يلى دئى * تجويزه التقويض وهو نرك التأويل مع الثروط السابقة وهى نفى الجهات والدحاذيات والكيفية والكمية .

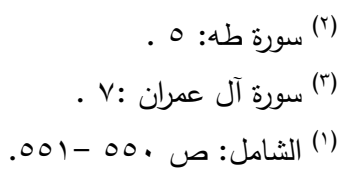




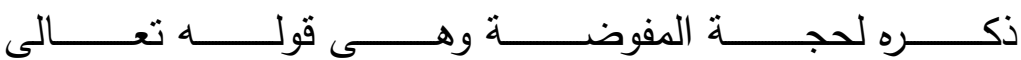

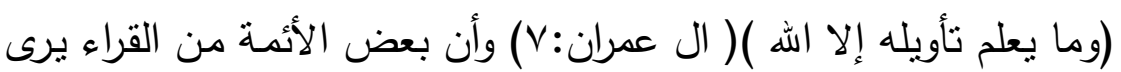

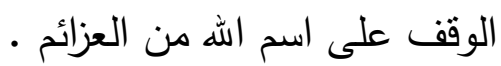

والذي يفهم من حجة المفوضة منع التأويل فما هو موقفه ؟ الهن

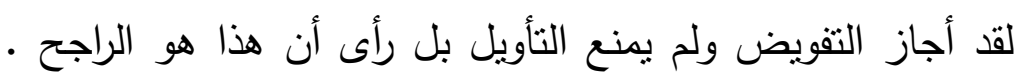
ويتضح لنا ذلك من النص التالي إذ يقول : ( وقد سلك معظم أهل الحجاج طريقة التأويل ، وقد قدمنا في ذلك طرفا ، وبينا أن الذي يجتتبه

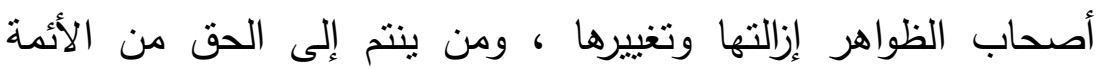

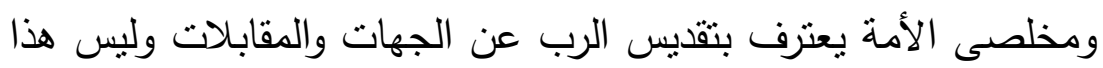

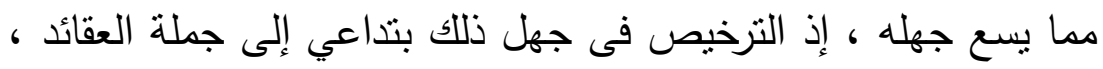

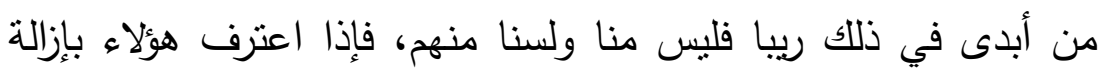

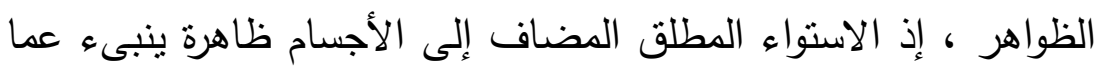

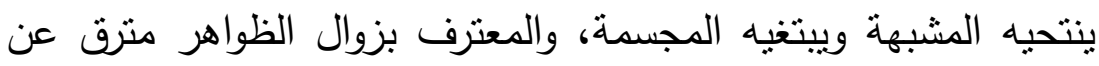

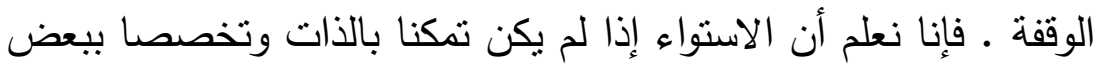

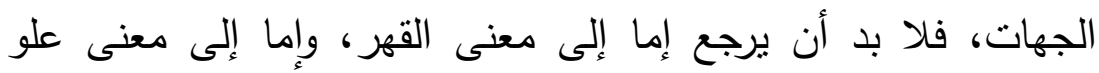

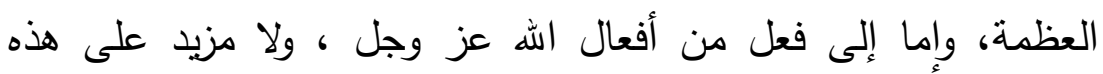

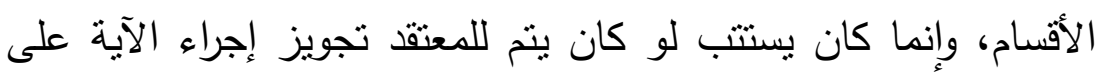

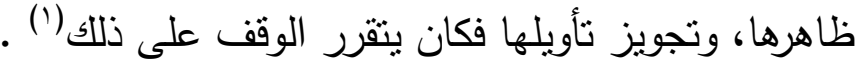

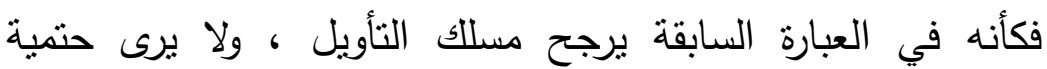
التفويض وهكذا يتضح أن موقف الجويني من تأويل آيات العقيدة في مرحلة

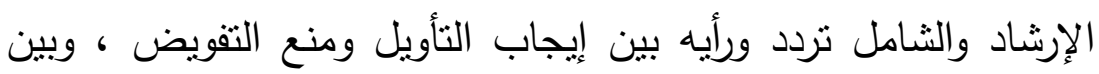
تجويز التقويض وترجيح التأويل .

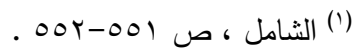




\section{طرق التاويل عند امام الحرمين}

يسلك إمام الحرمين عدة مسالك في تأويل الظواهر السمعية حسب التب ما يقتضيه المقام وذلك على النحو التالي : - صرف اللفظ عن ظاهره بتقدير مضاف محذوف . - صرف اللفظ بحمل الإضافة على إضافة التملك ، لا إضافة الصفة

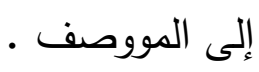
- إذا كان ظاهر اللفظ العموم خصصده . - إذا كان ظاهر اللفظ مطلقا قيده . - يؤول بحمل اللفظ على معنى آخر يحتمله احتمالاً مرجوحاً .

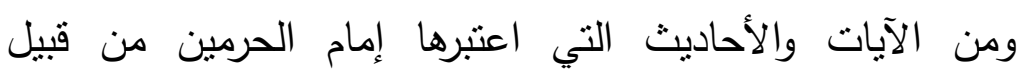

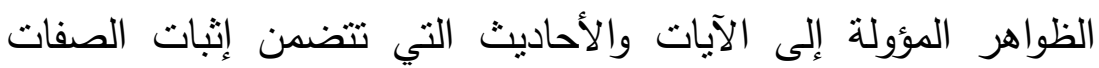
الخبرية الطوال

فالصفات الخبرية كالوجه واليدين والعين والقدم والساق والجنب والنزول والاستواء والمجىء والإتيان جميعها لم يتثتها إمام الحرمين الهه

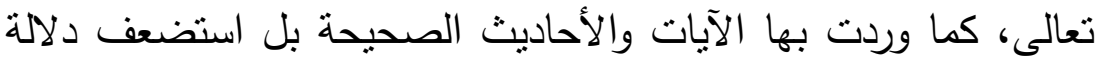

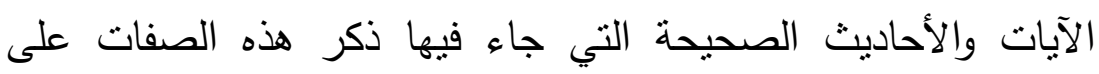
معانيها الدالة علبها ذلك للأسباب النالية : - إن هذه الصفات لا تثبت عنده عقلا ومن ثم فظاهرها غير مؤيد

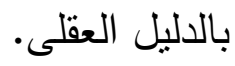

- بعض هذه الصفات يناقض الدليل الدال على حدوث العالم ، والدليل

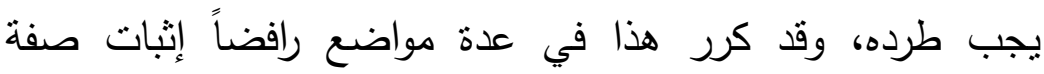

$$
\text { الاستواء والنزول والمجىء. }
$$

- أما البعض الآخر كالوجه واليدين ، فهو يرى أنها لو أثنتت سمعا كما

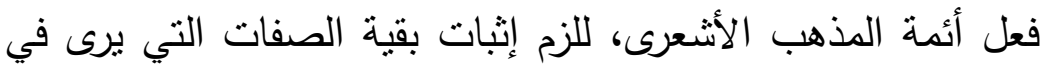




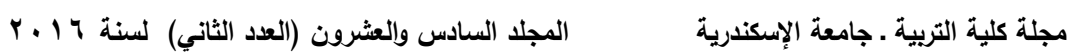

إثباتها الله تعالى إما وصفه تعالى بالحدوث ، أو إبطال دليل حدوث

- العالم

تأويله لصفة اليدين

عند قوله تعالى لإبليس : ( ما منعلك أن تسجد لما خلقت بيدي )(')

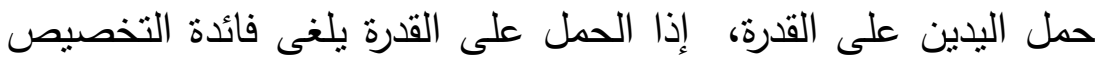
وبيان تميز آدم عليه السلام على إبليس ، إذ جميع المخلوقات مخلوقة

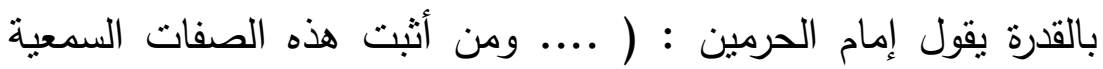

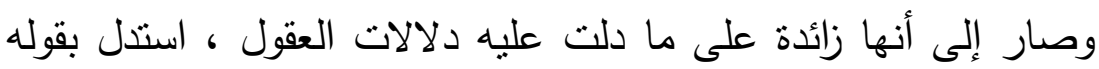

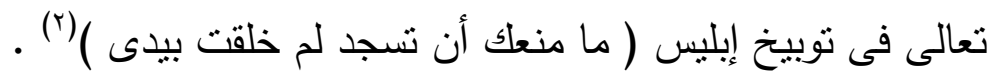

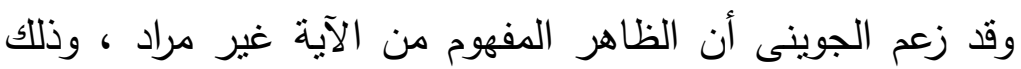

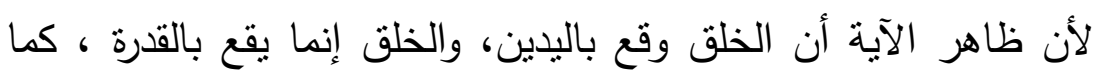

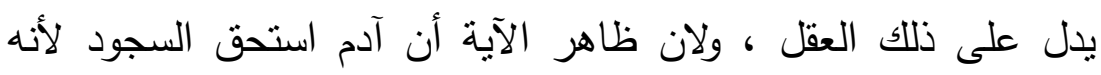

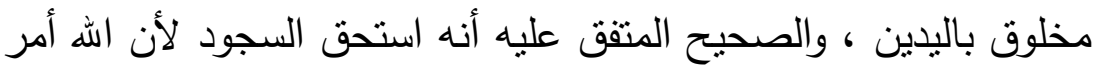

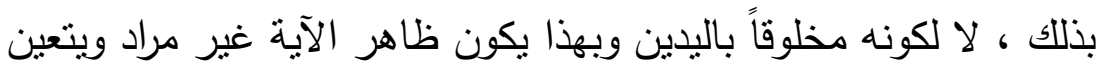

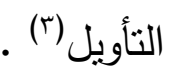

\section{تأويله لصفة العين}

كذلك أخطأ إمام الحرمين في تأويل الآية التي جاء فيها إثبات صفة العين لله تعالى وهى قوله تعالى : ( تجرى بأعيننا)(؛) فهذه الآية عند

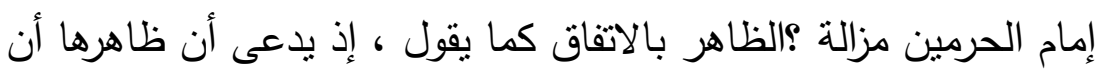

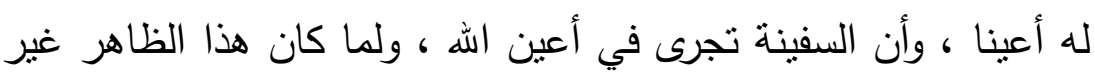

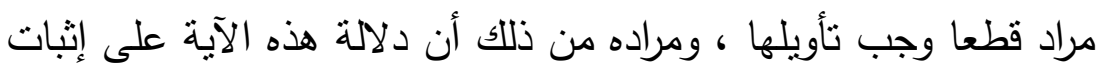

$$
\begin{aligned}
& \text { (') سورة ص : آية Vo . (1) }
\end{aligned}
$$

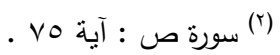

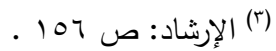

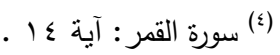




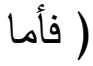

صفة العين ليست قطيعة ، يقول إمام الحرمين : الآية الششتلة على ذكر العينيين فمزالة الظاهر اتفاقاً ـ وكنلك قوله

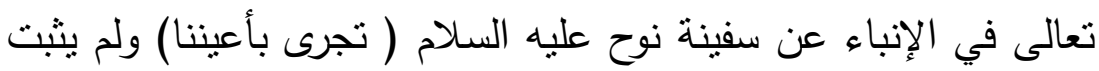
أحد من المنتمين إلى التحقيق أعينا لله تعالى ، والمعنى بالآية أنها تجرى

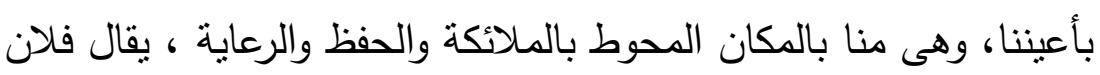

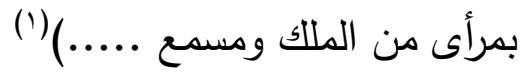
ومما نلحظه على نص إمام الحرمين السابق ما يلي

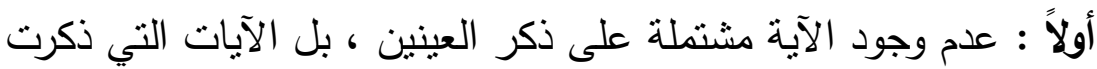

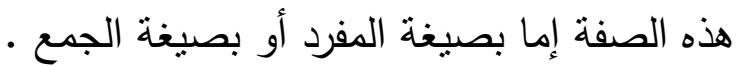
ثانياً : فات إمام الحرمين أن يقول : إن الآية ظاهرها يثبت آلهة كثيرة ،

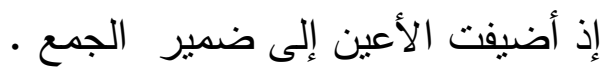

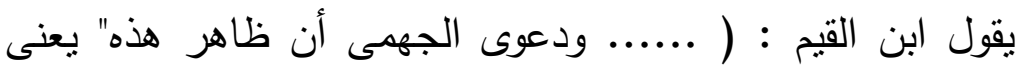

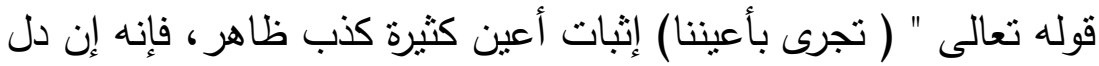
ظاهره على أعين كثبرة دل على خالقين كثبرين، وكذلك قوله ل

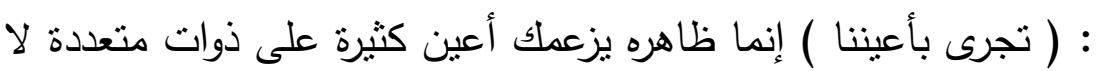

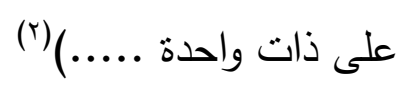

ثالثاً : من منع اتصاف البارى تعالى بعين واحدة ، استذل بما رواه البخارى عن رسول اله صلى الله عليه وسلم أنه قال :" إن ربكم ليس اليس

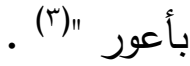


فبين ابن القيم أن هذا الحديث صريح في أنه ليس المراد إثبات عين واحدة ليس إلا ، فإن ذلك عور ظاهر ، تعالى اله عن ذلك علواً كبيراً . (') (...

تأويله لصفة ( الوجه )

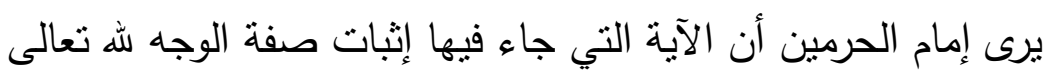
وهى قوله تعالى ( كل من عليها فان ويقى وجه ربك ذو الجال والإكرام

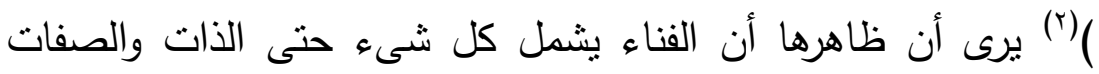
الإلهية ما عدا صفة الوجه هذا هو الظاهر في نظر إمام الحرمين .

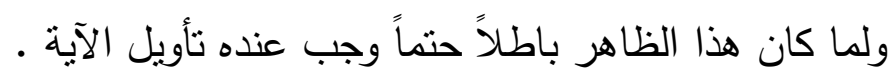

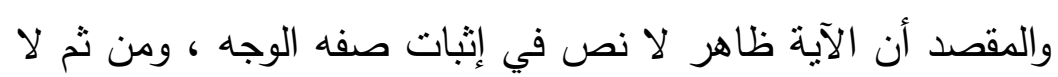
تثبت بها تلك الصفة بل يجب تأويلها عنده .يقول إمام الحرمين الابه

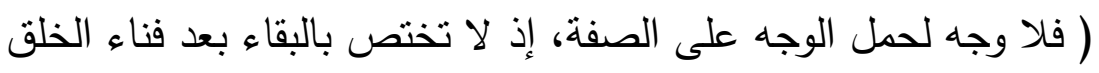

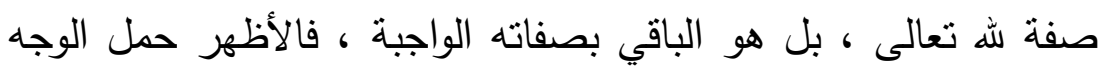
على الوجود)(r) وكلام إمام الحرمين ظاهر السقوط ، فلا أحد فهم من ظاهر الآية

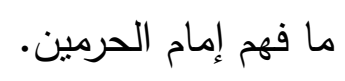

بل إن السلف الصالح منعوا الجهية من الاستدلال بهذه الآية على الحئ

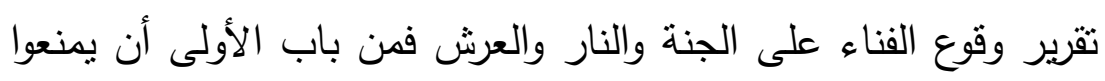

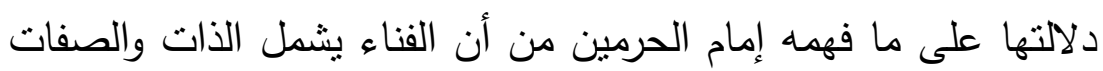

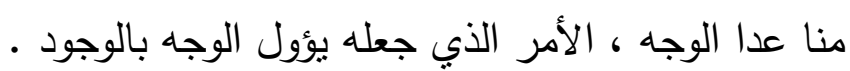

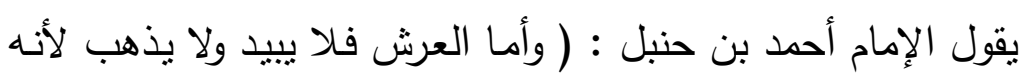

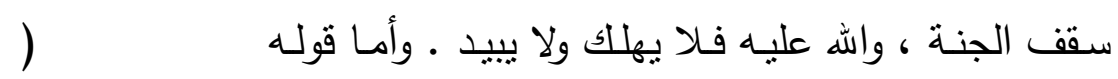

$$
\begin{aligned}
& \text { (') الصواعق المرسلة :ص (rON/1) (1) ). }
\end{aligned}
$$

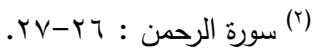

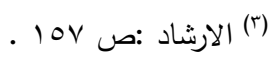




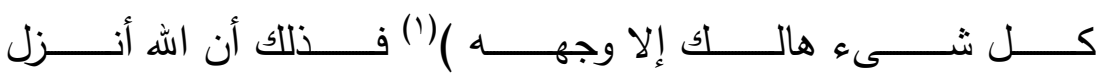
( كل من عليها فان)(؟) قالت الملائكة : هلك أهل الأرض وطمعوا في البقاء فأنزل الله أن يخبر عن أهل السموات والأرض أنكم تموتون ، فقال كل شىء من الحيوان هاللك يعنى ميت إلا وجهه أنه حي لا يموت فأيقنوا

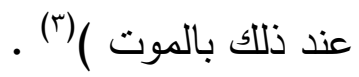
ثم إن هناللك أحاديث كثيرة تتضمن إثبات هذه الصفة أعنى الوجه •لبارى تعالى فمن ذللك الأدعية التي دعا بها الرسول صلى الله عليه وسلم سائلاً

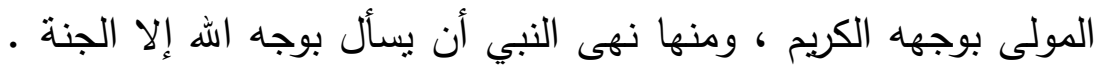

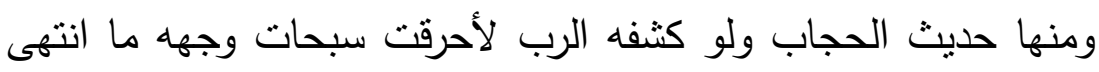
إليه بصره(£) .

إلى غير ذلك من الأحاديث التي تعتبر من القرائن الدالة على التى

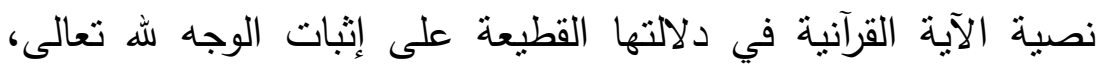
وتبطل اعتبارها من الظواهر المؤولة كما فعل إمام الحرمين. وفى تقرير ذللك والتأكيد عليه . يقول ابن القيم: ( أن من تدبر سياق الآيات والأحاديث والآثار

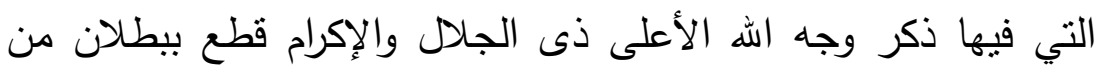
حملها على المجاز .......). تأويله لأيات المعية

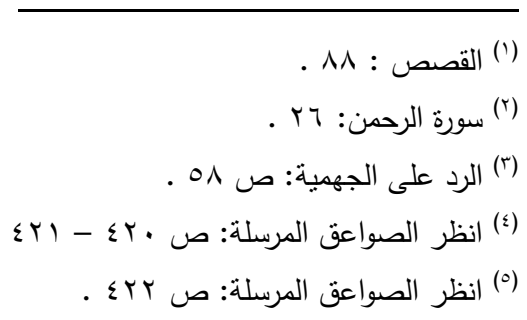


وقد اعتبر إمام الحرمين آيات المعية من قبيل الظواهر حيث أخطأ

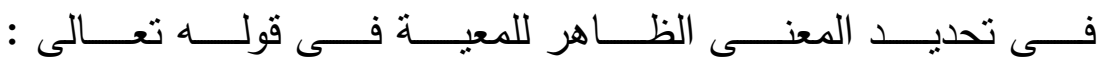

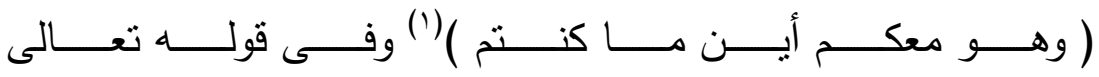

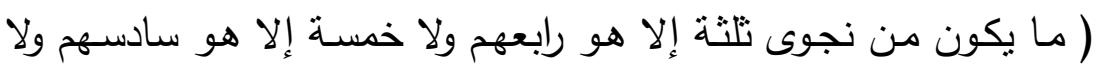

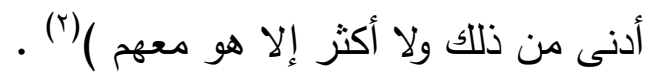

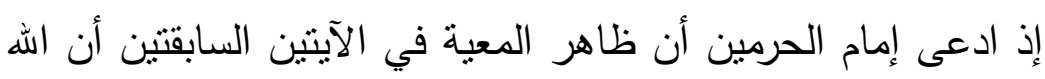

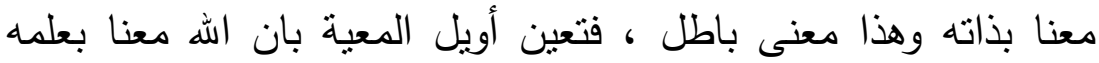
واحاطته .

وإمام الحرمين إنما قال ما قال ليلزم الحشوية على حد تعبيره بوجوب تأويل ما يثبتونه من بقية الصفات الخبرية ، ما داموا يفسرون المعية

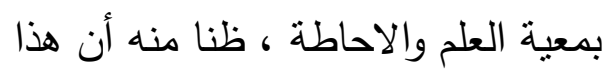
التفسير منهم للمعية من قبيل التأويل بصرف اللفظ عن معناه الظاهر

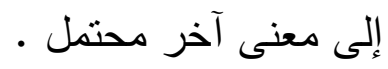

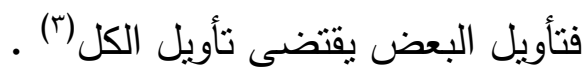

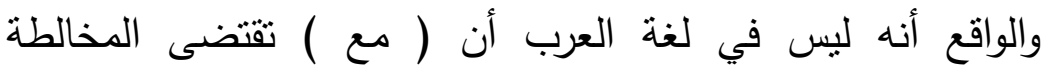

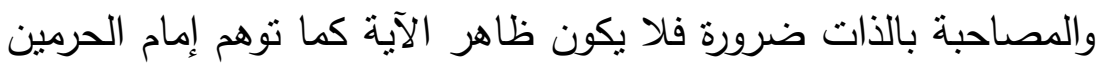

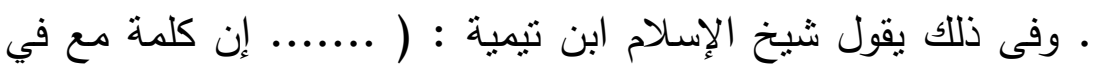
اللغة إذا أطلقت فليس ظاهرها في اللغة إلا المقارنة المطلقة ، من غير الئل

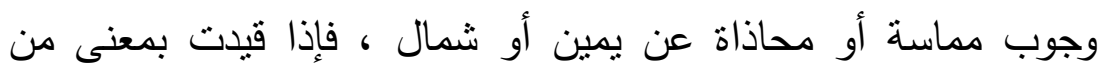
المعاني دلت على المقارنة في ذللك المعنى ) .

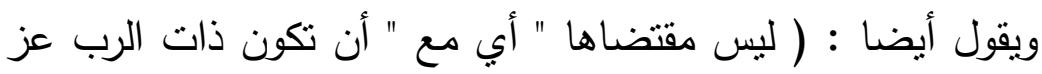

وجل مختلطة بالخلق، حتى يقال قد صرفت عن ظاهرها )(') 


\section{( خلاصة ما انتهى إليه الجوينى )}

تأثز أبو المعالى الجوينى بالفلسفة اليونانية ، وببعض آلهاء آلهاء المعتزلة ،

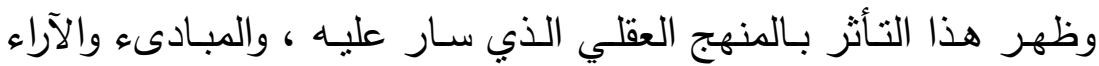

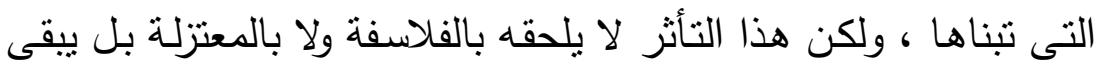

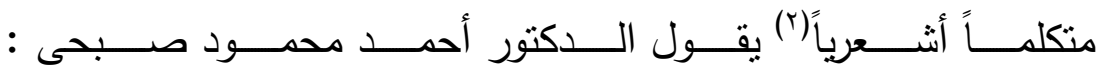
( أفاد الجوينى من فلسفة اليونان التي أكسبته - كما أكسبت غيره من

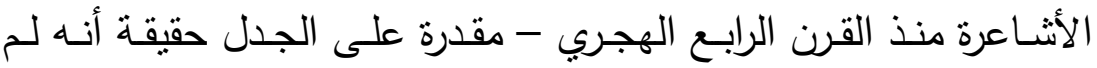

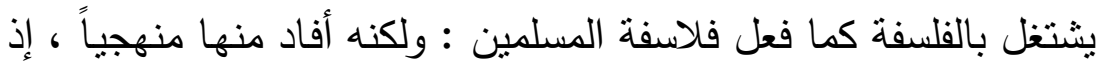
نجده يقدم للمصـلحات الكلاميـة والفلسفية ويقدم للنظريـات الكلاميـة بأبحاث فى المعرفة، وكذللك انعكست الثقافة الفلسفية على نسقه الكلامى

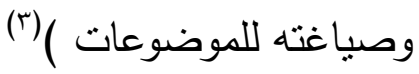

وفى حين أن الأشعرى والباقلانى كانا يوجهان نقدها للمعتزلة والمعطلة نجد أن الجوينى بركز هجومه على الحشوية، ويقصد بهر أهل

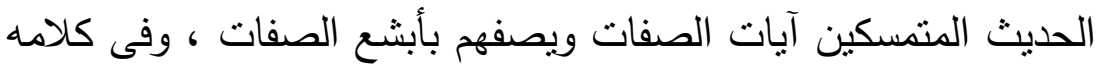
عن المعطلة بوجه كلامه للفلاسفة والباطنية ، ويلاحظ أنه لا يذكر ولئح المعتزلة من بين المعطلة|(ई) . ولقد أثبت أبو المعالى الجوينى صفات المعاني لله تعالى كالسمع

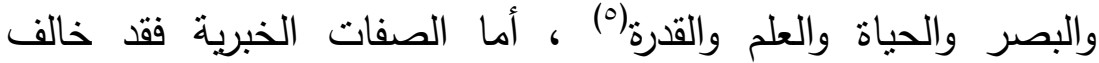

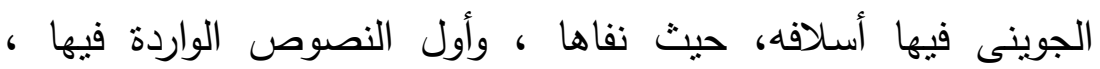

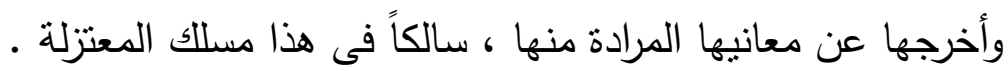

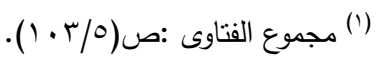

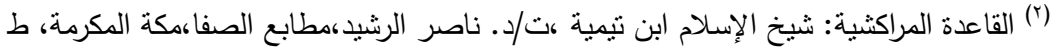

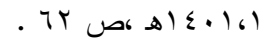

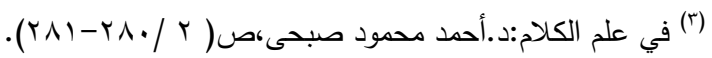

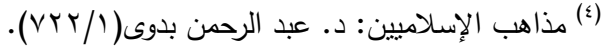

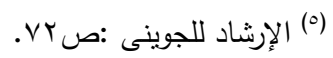


وقد أعترف الجوينى نفسه بمخالفته من سبقه حيث قال :

( ذهب بعض أئمتنا إلى أن اليدين والعينين والوجه صفات ثابتة للرب إبه تعالى ، والسبيل إلى إثباتها السمع دون قضية العقل والذي يصح عندنا

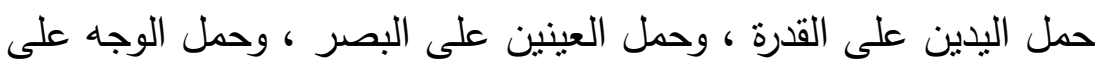

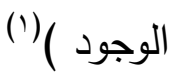

لكن المحير في أمر المتكلمين هو أنه قد رجع في آخر حياته عن

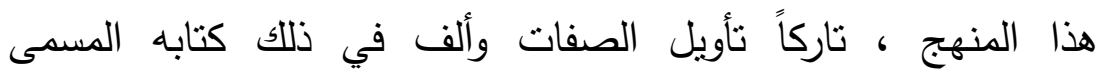
( بالعقيدة النظامية ) وقال فيه : ( وقد اختلف مساللك العلماء في الظواهر التي وردت في الكتاب والسنة فرأى بعضهم تأويلها وذهب أئمة

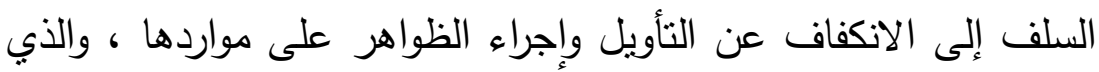

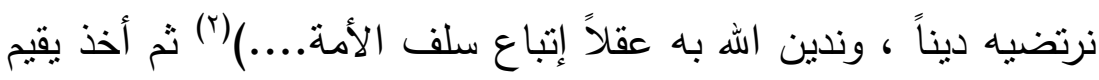

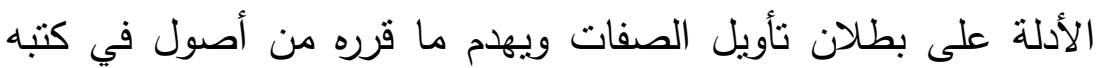
السابقة .

وكان من آخر ما قال عند موته : ( اشهدوا أنى قد رجعت عن كل

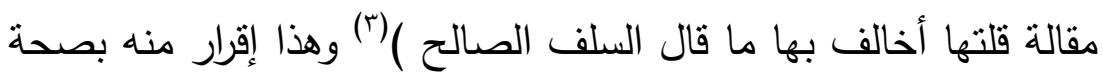
منهج السلف وفساد طريقة الخلف ومن العجيب أن الأثاعرة المتأخرين يأخذون بأقوال الجوينى السابقة ولا يعتمدون رأيه الأخير الذي مات عليه النيه

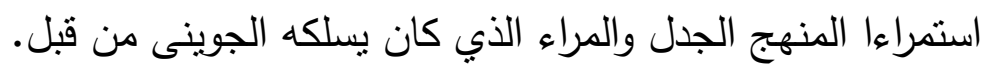
- رد أهل السنة والجماعة علي المجازيين في بعض حدودهم وقواعدهم التي وضعوها : 
بعد أن علم أن التقسيم إلى حقيقة ومجاز كان تقسيماً إصلاحياً، وأن أول نشأته جهة المعتزلة والجهية ما ذكر ذلك عن ابى هاشم حيث عد إنى إنى إنى

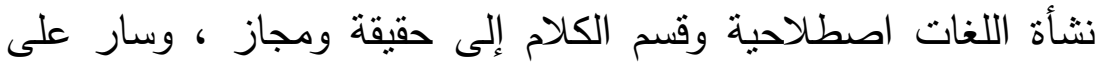
ذلك المتكلمون فوضعوا لذلك ضوابط وحدود وعلامات لكنها متتاقضة متهافتة .

وقد تصدى علماء أهل السنة والجماعة لهذه الأقوال ولهذا التقسيم ولتلك الحدود والضوابط، ولعل من أثنهر من كان لهم باعاً في تلك ولك الردود شيخ الإسلام ابن تيميه وتلميذه ابن قيم الجوزية والذين نستقى من هن

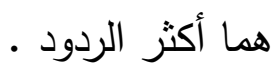
الرد علي ( المتكلمين ) من حيث التقسيم الرد على المتكلمين في تقسيم الكلام إلى حقيقة ومجاز يقول شيخ

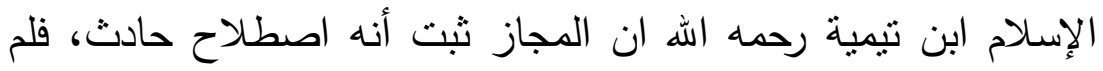

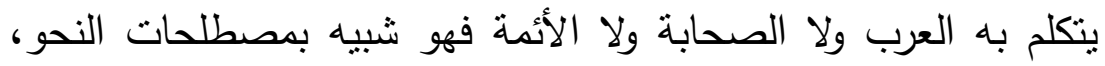
ولكن النحو جاء اصطلاحاً مستقيماً وليس فيه مفسدة، وأما المجاز فهو اصطلاح غير مستقيم وفيه مفاسد عقلية وشرعية ولغوية ، أما المفسدة ولهاء ولهيه العقلية فهى عدم تمييزه ظاهراً صحيحاً . أما الثرعية : فقيها مفاسد يوجب الثرع إزالتها إلا وهى تحريف كلام الله عز وجل وكلام رسوله صلى الله عليه وسلم عن حقبقته وحمل

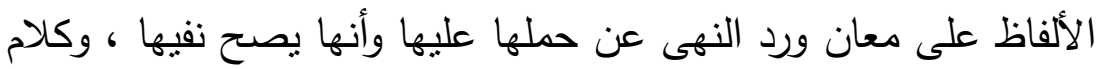
الله عز وجل كلامه حق وعدل وصدق . أما اللغوية فهي تغيير للأوضاع اللغوية لغير مصلحة وردة راجحة بل لمفسدة (1). 
وهذا الكلام كما تقدم معنا : يبين أن التقسيم ليس تقسيماً عقلياً أو شرعياً أو لغوياً وأن جميع هذه الأقسام في حقه غير صحيحة لأن العقل لا مدخل له في دلالة اللفظ وتخصيصه بالمعنى المدلول عليه، وإلا فلو لوه كان للعقل مدخل في ذلك لكانت اللغات واحدة ،ولما اختلف باختلاف

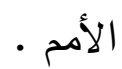

أما اللغة فلم ينقل أن أحداً من أئمة العرب المعتمدين قسم ذلك التقسيم .وأما الثرع فلم يدل على ذلك لا في كتاب ولا سنة ولا قول السلف الصالح والأئمة المعتبرين بل هو تقسيم مبنى على معارضة نصوص الكتاب والسنة ومفاسده عظيمة جداً حيث تمس أصل الدين وعماده فى باب الاعتقاد وأسماء الله وصفاته .

وممـا يطعن في تقسيمهم الكـلام إلى حقيقة ومجـاز عد انضباط

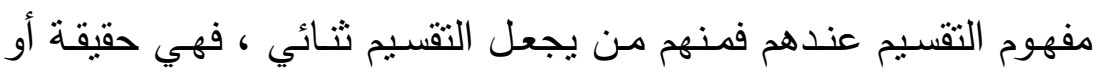

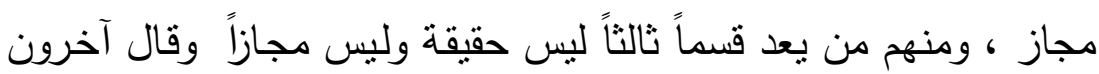

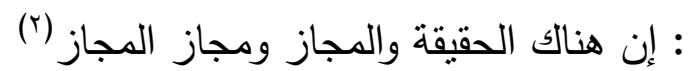

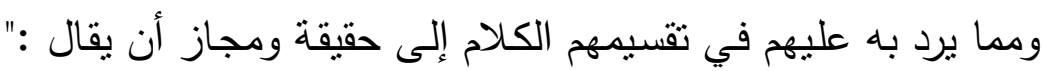

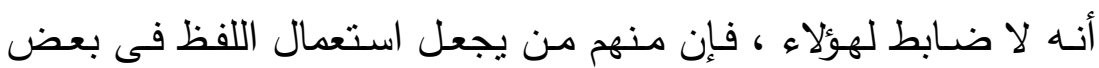
معناه حقيقة ومنهم من يجعله مجازاً ، ومنهم من يجعله حقيقة ومجازاً

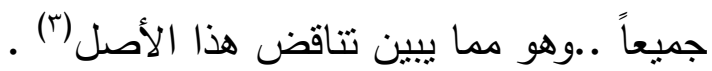
وهذا يبين تتاقض أقوالهم وحدودهم التي وضـعوها ـ يقول شيخخ

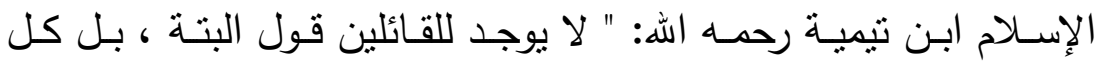

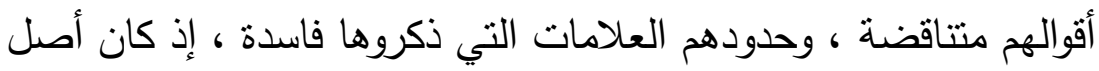

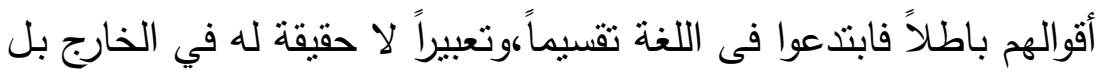

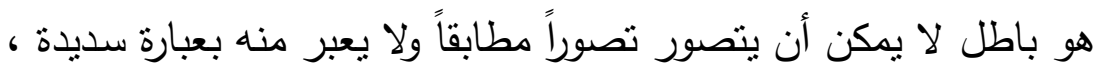

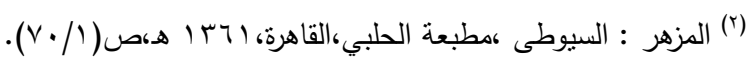

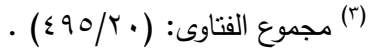


بخلاف المعنى المستقيم فانه يعبر عنه بالقول الثديد ، قال تعالى يأيها

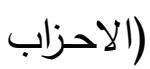

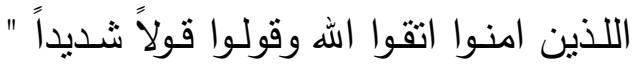
( $v$.

والسديد : السـاد الصـواب المطابق للحق بـلا زيادة ، ولا نقصـان (')

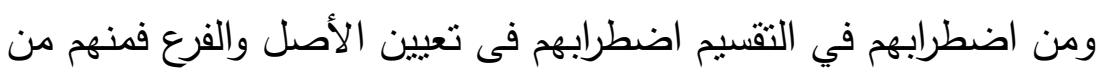

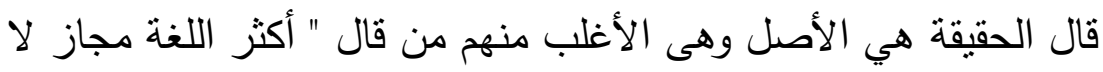

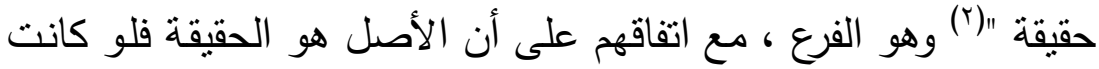

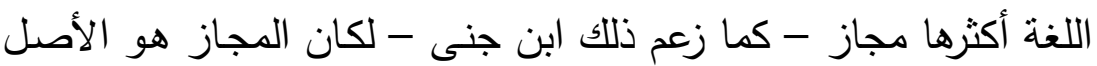
- لأن الأصل هو الغالب الأكثر - وهم يناقضون ذلك فيقولون المجاز

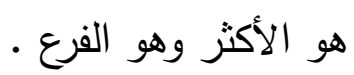
فنجد أن قولهم : أكثر اللغة مجاز يناقض قولاً آخر لهم ، وهو قولهج

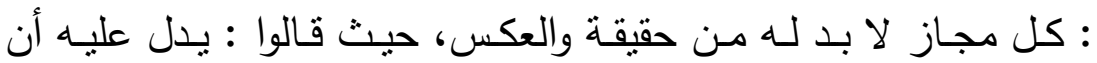

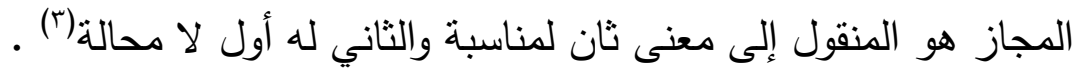

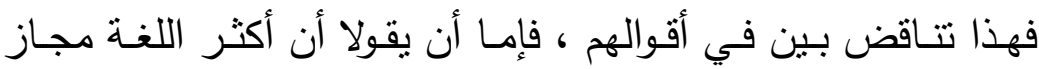
وينفوا أن يكون لكل مجاز حقيقة . وأما أن يقولوا أن أثز اللغة حقيقة وهيفة الأنس الأصل والمجاز هو الفرع

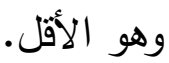

هذا وقد أدعى ابن جنى ، أن عامة الأفعال نحو قام زيد، وقعد عمرو ، مجاز لأن الفعل يفاد منه معنى الجنسية ، فقولك : قام زيد الته

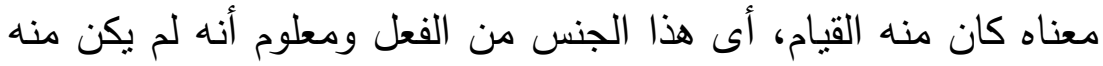

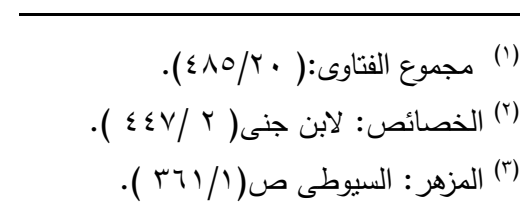


جميع القيام في الماضي والحاضر ، والأتي الكائن من كل من وجد منه

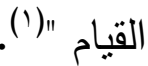

بل بلغ به الأمر أن بعد من الجائز أن نقول :" ضربت زيداً وتقصد

غلامه "(r)

وعلى هذا فالمجاز هو الأكثز - عند ابن جنى - لا الحقيقة وهذا

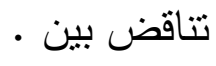

الرد (المكلمين ) من حيث الوضع

حيث كثيراً ما يرد قولهم : هذا اللفظ مستعمل فيما وضع له ، ، وهذا

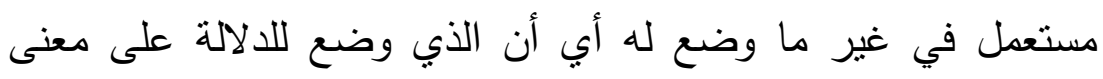

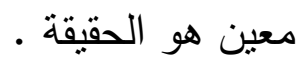

والمنقول عن ذلك الوضع إلى معنى آخر هو المجاز •

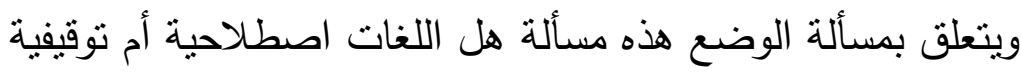

وحدهم للهجاز بأنه اللفظ المستعمل في غير ما وضع له والحقيقة

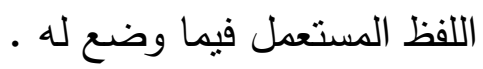

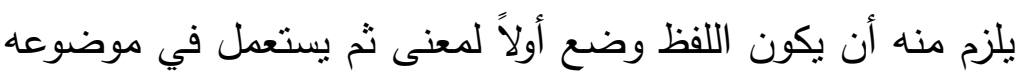

وقد يستعمل في غير موضوعه .

وعلى هذا الحد يترتب الحكم فى مسألة مبدأ اللغات ولكن مما برد

به عليهم هنا : أن التعريفات التي ذكروها لا تتبت أمام المناقثنة العلمية

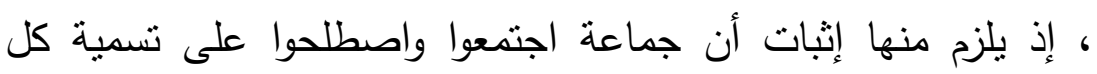

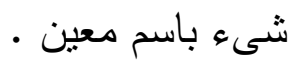

كما بلزم أيضاً من القول بالاصطلاح خروج الحقيقة الثرعية

والعرفية من حيز الحقيقة إلى المجاز ، إذ التعريف الذي وضعوه لا بد بد بـاج

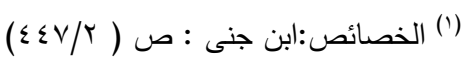

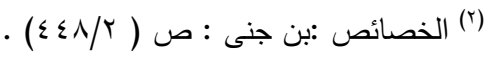


أن يكون جامعاً لجميع ما يتعلق بالتعريف والحقيقة الثرعية والعرفية لا تخخل تحت الحقيقة اللغوية . ويلزم أيضاً من القول بالاصطلاح ما يترتب عليه من الدور

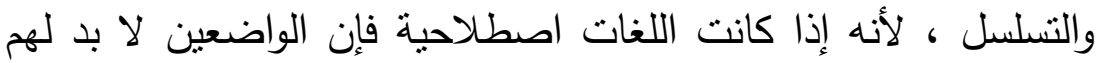
من اصطلاح آخر يضعونه حتى يحصل بينهم التفاهم وذلك يستلزم

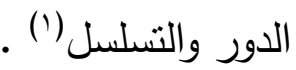

فقولهم " المجاز كل كلمة أريد بها غير ما وضعت له فى وضع واضعها تعريف فاسد لأنه يقتضى خروج الحقيقة الثرعية والحقيقة العرفية إلى حد المجاز، لأن كل واحد منها قد أريد به ما هو أعم من لند

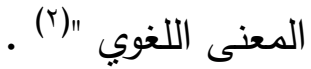
أيضاً يقال لهم

هل العلة فى نقل اللفظ من الحقيقة إلى المجاز لغاية لغوية أو

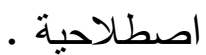

فإذا كان لغاية لغوية فمعناه مثناً أن ظاهر اللفظ موهم أو نحو ذلك، فأعمال المجاز بقصد توضيحه أو تبينه يؤدى بنا إلى تعطيل

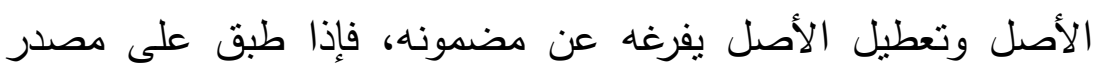

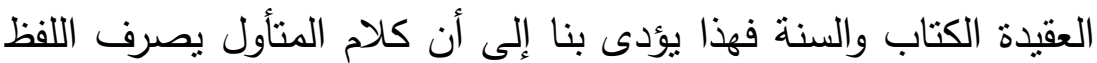

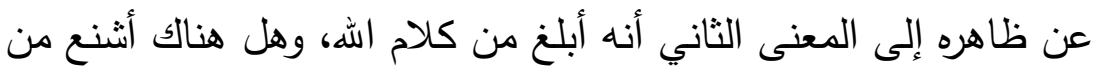
هذا القول وإن لم يقولوه ، ولكن هذا لازم قول من يعمل المجاز ويسلطه

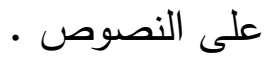

(1) الدور : توقف الثىء على ما ينوقف عليه والتسلسل : ترتيب أمور غير متتاهية ،

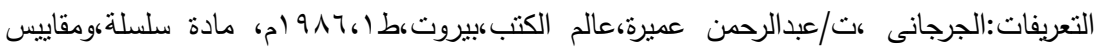


- فالكلام يستقيم بدون أن يدعى المجاز ، ومنهج المتكلمين في أعمال

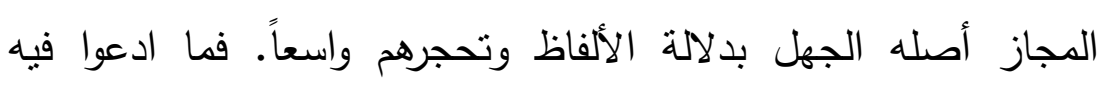
المجاز سواء من كلام العرب أو كلام الله ورسوله يفهم بدون حاجة لتقدير مجاز وتوضيحه .

أما إذا قالوا بل نقل اللفظ من الحقيقة إلى المجاز لغاية اصطلاحية

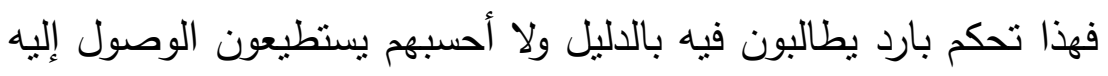

وأيضاً قولهم : إن المجاز ما كان قليل الإطلاق والاستعمال، كال، كان. والحقيقة ما كانت كثيرة الإطلاق والإستعمال . والجواب عن قولهم من وجوه ا-أن كثيراً من الألفاظ تعد نادرة الاستعمال ولم تخرج مع ذوه ذلك عن كونها حقيقة . أن كثيراً من المجازات عندهم. قد غلبت على الحقيقة، بحيث صارت المعاني الحقيقية مهجورة أو مغمورة .

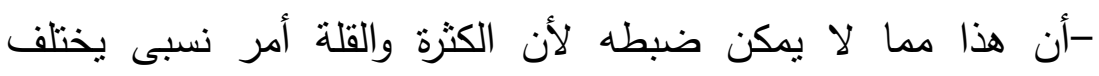
باختلاف الأزمنة والأمكنة والأشخاص ، فما لألهان الذي يضبط به الكثرة

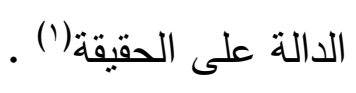

وأيضاً حدهم بالمجاز بصحة نفيه حيث أدعوا أن المجاز يصح نفيه.

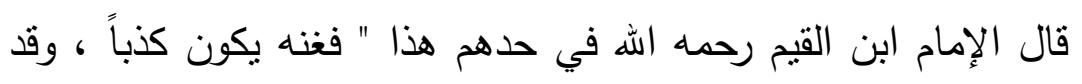

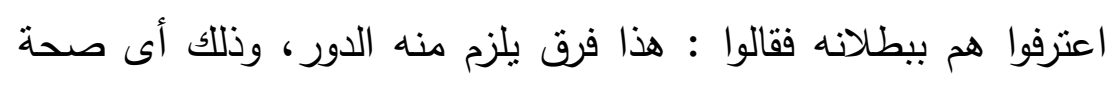

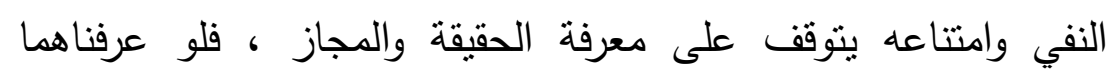
بصحة النفي وامتتاعه لزم الدور "(1).

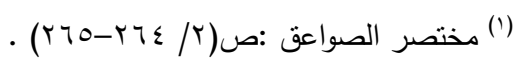

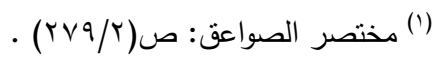


ومما يؤكد أنه يلزم الدور من ذللك إن صحة النفي مدلول عليه

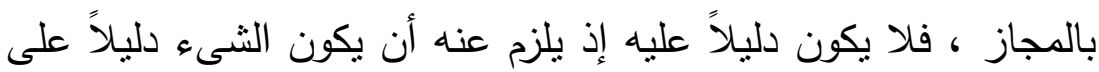

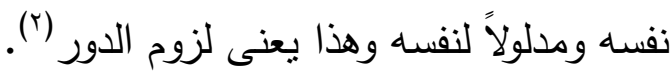

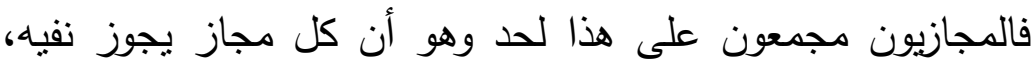

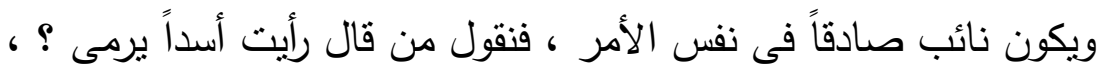

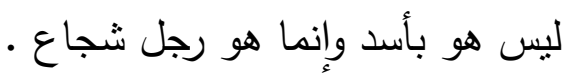
كما أن الخطر المترتب على هذا القول يمكن أن يؤدى إلى أن يكون في القرآن ما يجوز نفيه لقولهم بوقع المجاز في القرآن ـ

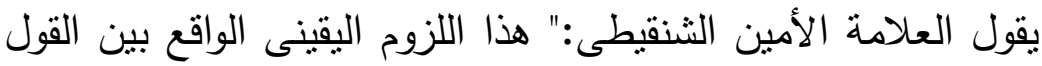
بالمجاز في القرآن وبين جواز نفى بعض القرآن قد شوهد في الخارج صحته، وأنه كان ذريعة إلى نفى كثير من صفات الكمال والجلال الثابتة الله في القرآن العظيه . وعن طريق القول بالمجاز توصل المعطلون لنفى ذلك فقالوا : لابد، ولا استواء، ولا نزول.... ونحو ذلك في كثير من آيات الصفات، لأن هذه الصفات لم ترد خصائصها، بل هي عندهم مجازات، فاليد مستعملة

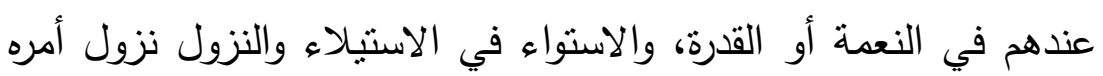
- (....

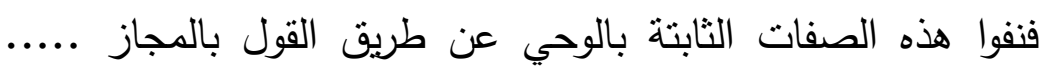

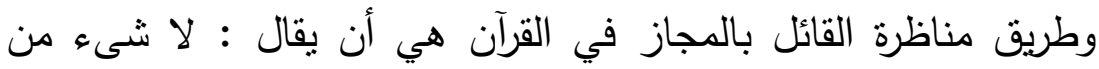
القرآن يجوز نفيه، وكل مجاز يجوز نفيه ينتج من الثكل الثاني لا شىء من القرآن بمجاز ، وهذه النتيجة كلية سالبة صادقة "(() .

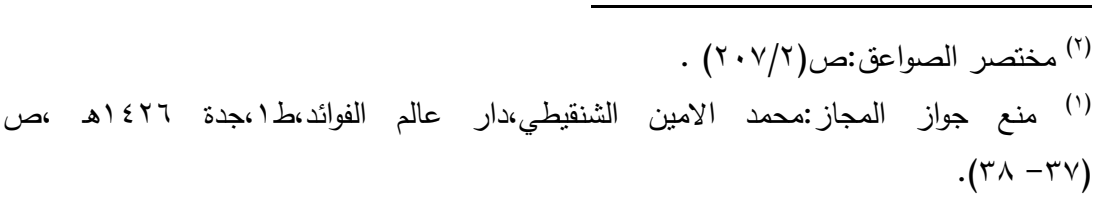
r. 
فالمجازيون يجعلون صحة النفي دليل على مجازية الكلام لأن الحقيقة هي التي لا يصح نفيها . فئون

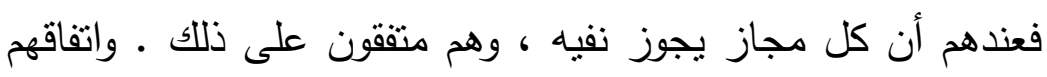

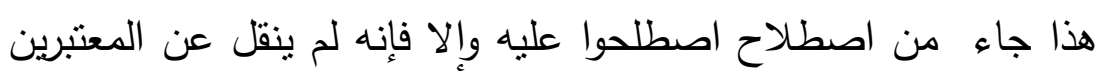
من الأئمة وأ. ويترتب على تاصيلهم هذا الحد القول في القران او في كلام الله وكلام رسوله ما يصح نفيه.

وقد نوصلوا بهذا الحد إلى نفى الصفات الثابتة في الكتاب والسنة حيث إنها في اعتقادهم مجازات يصح نفيها فنكون النتيجة إنه لا استواء

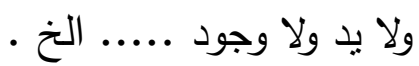
يقول شيخ الإسلام في ذلك" فإذا قالوا أن هذه الأسماء مجاز أمكنه

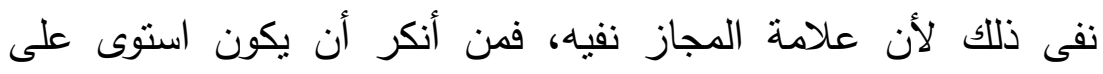

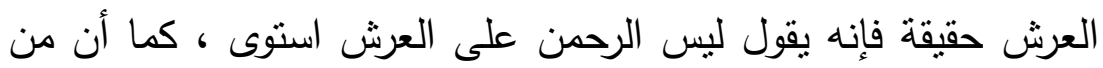
قال أن لفظ الأسد للرجل الثجاع والحمار للبليد ليس بحقيقة، فإنه بلزمه

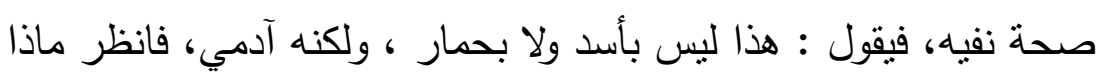
جنى التأويل على أهله من طامات.

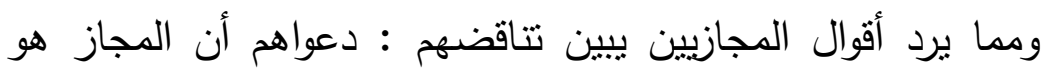

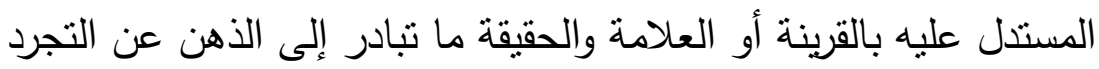
من القرائن يقول ابن القيم ، فهذا الفرق مبنى على دعوى باطلة وهى القى تجريد اللفظ عن القرائن بالكلية والنطق به وحده، وحينئ يتبادر منه الحقيقة عند التجرد .

وهذا الفرض هـ الذي أوقعهم في الـوهم فـإن اللفظ بـدون القيد والتركيب بمنزلة الأصوات التي ينعق بها لا تقيد فائدة، وإنما يفيد تركيبه

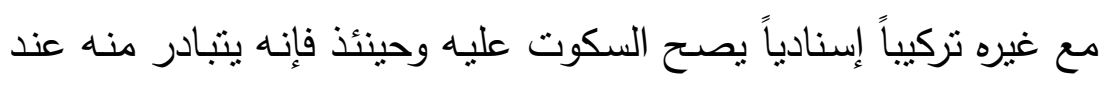


كل تركيب بحسب ما قيد به ـ فيتبادر منه في هذا التركيب ما لا يتبادر

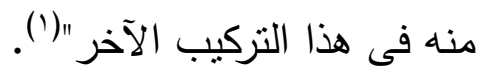

وقال أيضاً :" فإن اللفظ المفرد لا يفيد بإطلاقه وتجرده شيئًا البتة فلا

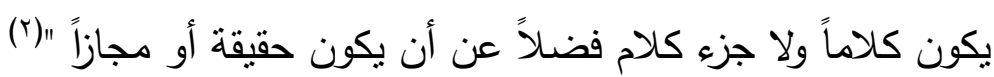

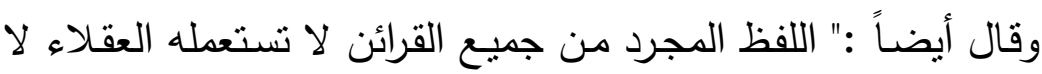
من العرب ولا من غيرهم ولا يستعمل إلا مقيداً، والاستعمال يقيده مطلقاً

مثال ذلك : كلمة " نزلا " في القرآن

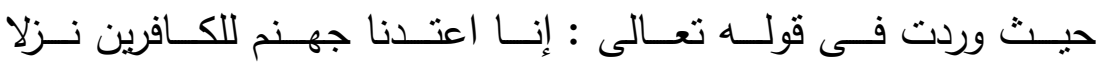

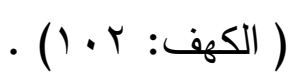

وفى قوله تعالى :" إن الذين آمنوا وعملوا الصالحات كانت لهم جنات

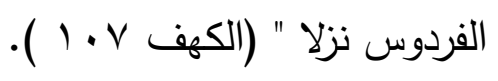

فالكلمة واحدة ولكن الفرق بين مدلولها بين كالفرق بين الجنة والنار ، النهار

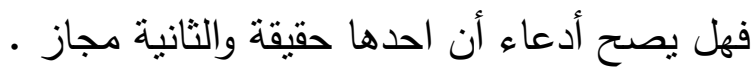
فالألفاظ لا يمكن أن تقوم مجردة، فالمعنى لا يتكون إلا بالتركيب

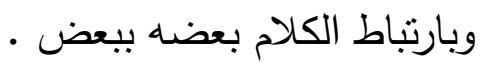
فتركيب الكلام ببعض مثل بإن

يقول ابن تيمية " بل لا يدل شىء من الألفاظ إلا مقروناً بنظيره من

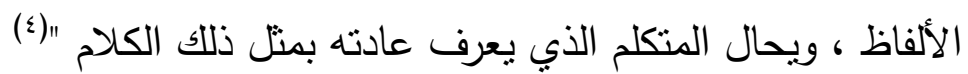
وكما ييين أن الكلمة لا يتضح معناها إلا بالقرائن

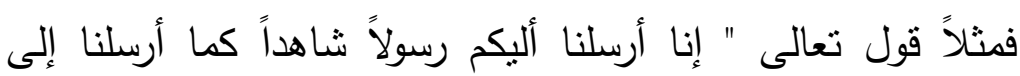

$$
\begin{aligned}
& \text { فرعون رسولاً " (المزمل: } 10 \text { ) ). }
\end{aligned}
$$

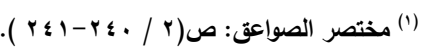

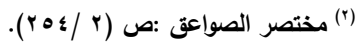

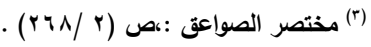

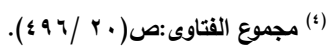


هذه الكلمة ( رسولاً ) هي هي بحروفها وشكلها ، وبالتركيب عرفنا

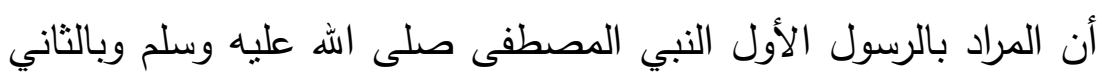

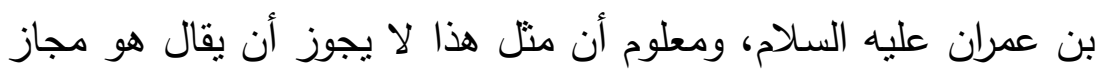

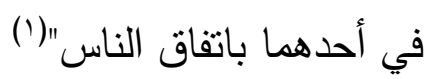

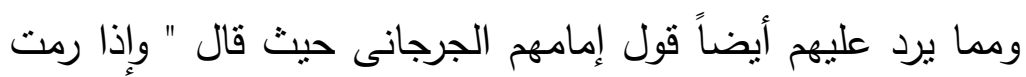
الفائدة أن تحصل للك من الاسم الواحد أو الفعل وحده صرت كأنلك تطلب إنب أنسان

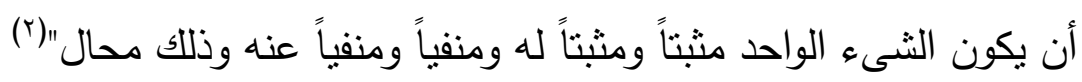
وبقال لهم أيضاً في رد هذا الحد : إن أردنم بالمجاز احتباج اللفظ

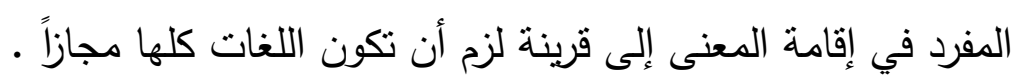

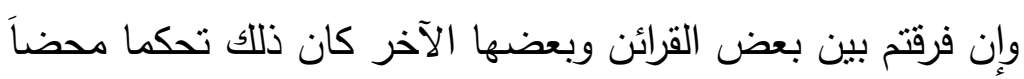

لا لا معنى له

ومما يرد على المجازيين قولهم يعرف المجاز بالاستدلال .

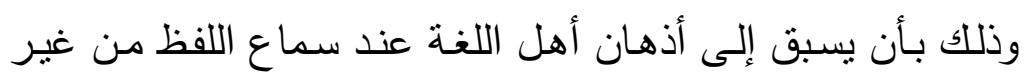
قرينة معنى من المعاني دون معنى آخر فقولهم يعنى : إن أمارة الحقيقة إنى

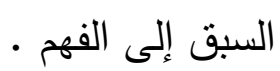

فيقال لهم :" أن العرب متفقون من أولهم إلى آخرهم على أن كل

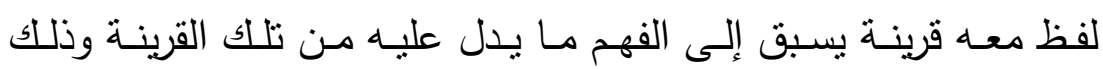
بالاضطرار لهم ، لم يوقفهم عليه موقف بل هو معهم من أصل النشأة

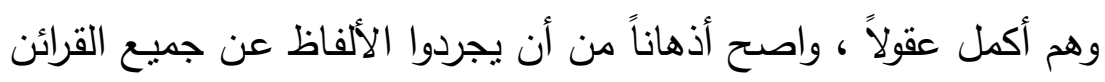

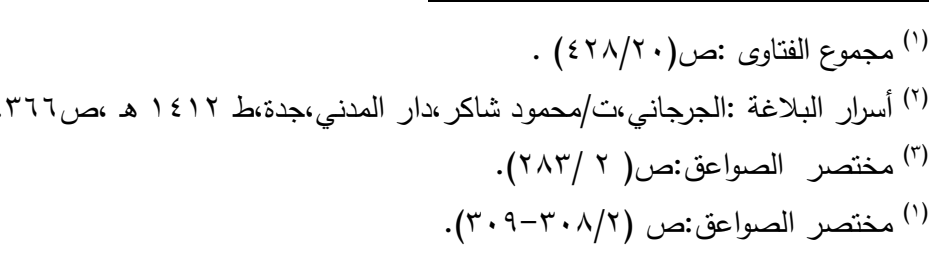


فبناء على أن اللفظ المفرد لا بمكن إقامته إلا بالقرائن فلا يمكن

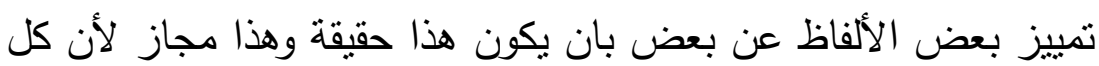
لفظ معه قرينة بسبق إلى الذهن ما يدل عليه اللفظ مع قرينته .

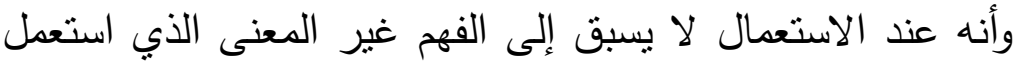
فيه ـ وهذا الكلام يناقض تطبيقاتهم المجازية، والا ممن يسبق إلى ذهنه عن قوله تعالى" وأسال القرية وأسأل الجدران " فهذا الحد الذي يحدوه دليل عليهم وعلى عكس مقصودهم وحدهم هذا وهو أن الحقيقة ما يسبق ولق ولقدان إلى الذهن حين الإطلاق، والمجاز يعرف بالاستدلال - على ما تقدم حد منهافت ودعوى باطلة إذ هي مبنية على إمكان تجريد الألفاظ من

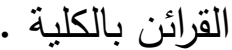

فمما يرد على المجازيين ما ادعوه من أن علامة الحقيقة السبق إلى بـ الفهم، واثتراطهم في أن تكون حقيقة في الاستعمال .

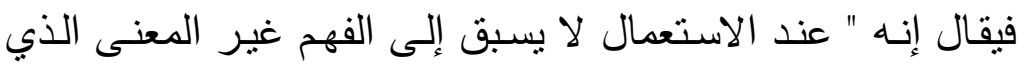

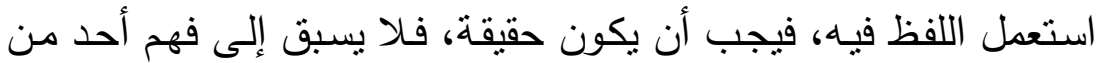
قول النبي صلى الله عليه وسلم في الفرس الذي ركبه " إن وجدناه لبحراً

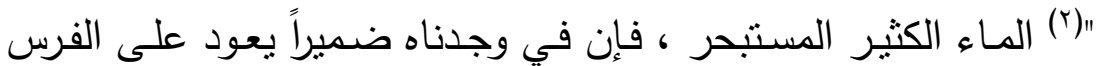

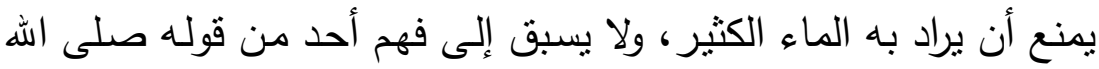

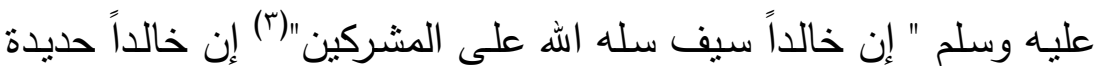

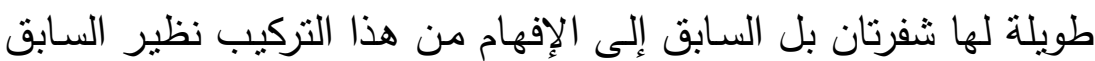

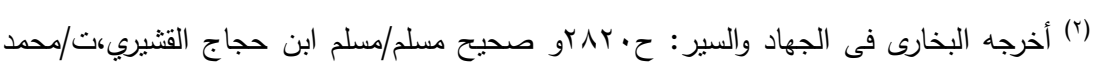

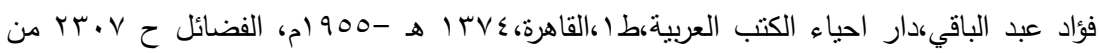

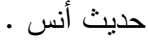

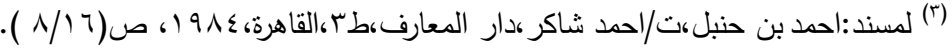


من قولهم " يـا رسول اله إنـا نركب البحر ونحمل معنا القليل من الماء

ونظير السابق إلى الفهم من قوله : " إنه قال لا إله إلا الهه بعدما علوته

بالسيف" (r) (بطيز

فكيف كان هذا حقيقة وذاك مجازاً ، والسبق إلى الفهم في الموضعين

واحداً ؟

وكذللك قوله صلى الله عليه وسلم في حمزة " إنه أسد الله ورسوله

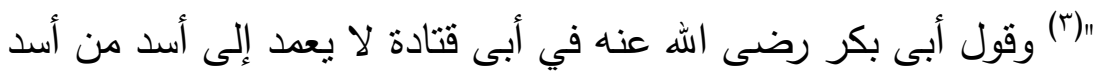

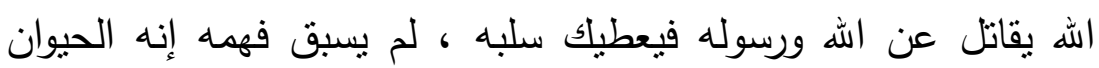
الذي يمشى، بل يسبق من قوله أن ثلاثة حفروا زبية أسد فوقعوا فيها

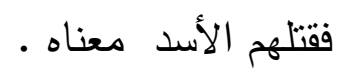

ولا يفهم أحد من قوله تعالى :" فأذاقها الله لباس الجوع والخوف " (النحل

(1) :

إن الجوع والخوف طعام يؤكل بالفم. بل هذا التركيب لهذا المفعول

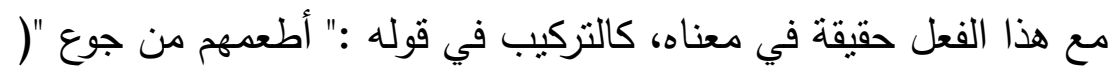

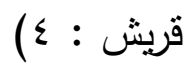

ونسبة هذا إلى معناه المراد به كنسبة الآخر إلى معناه ، وفهم أحد

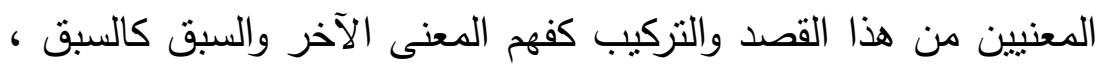

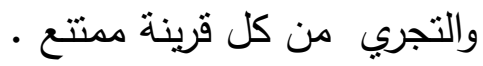

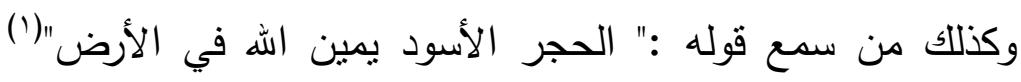

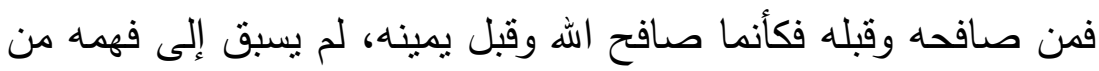

(') سنن الترمذى:التزمذي،ت/احمد محمد شاكر ،مصطفي البابي الحلبي،القاهرة،طء19 ام، ج 79.

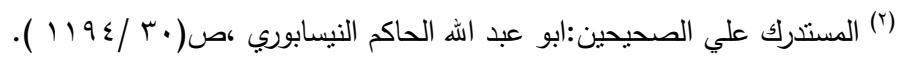

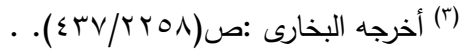

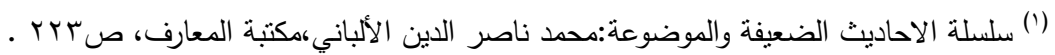


هذا اللفظ غير معناه الذي سبق له وقصد به ـ وإن تقبيل الحجر الأسود ومصافحته منزل منزلة تقبيل يمين الله ومصافحته . فهذا حقيقة هذا اللفظ، فغن المتبادر السابق إلى الفهم منه لا يفهم الناس منه غير ذلك ، ولا يفهم أحد منه أن الحجر الأسود هو صفة الله

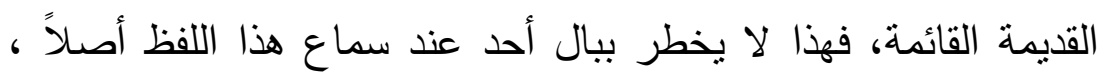
فدعوى أن هذا حقيقة وأنه خرج إلى مجازاة بهذا التركيب خطأ ، ولكنه

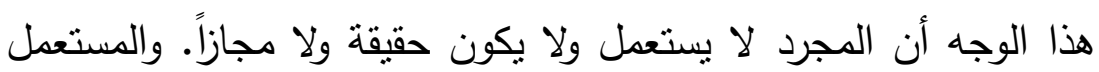
معه من القرائن ما يدل على المراد منه ويكون هو السابق إلى الفهم . والمقدمتان(r) لا ينكرهما المنازع ولا أحد من العقلاء وذلك ما يرفع المجاز بالكلية" (r).

وبناء على ما تقلم فقد ظهر أنه لا بد لكل لفظ من الارتباط بقرينة

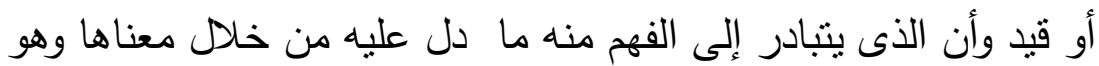

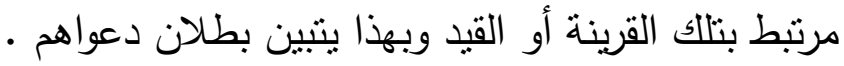
ثم إنه لا يمكن الوصول إلى الحقيقة حسب القواعد التي قعدوها والحدود التي حددها .

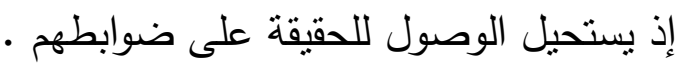

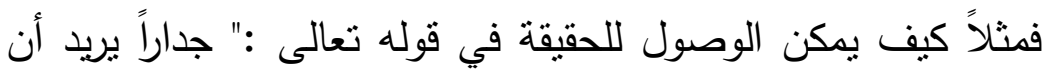
ينضض" (الكهف : VV ) فيقال لهم : ما حقيقة هذا المجاز ، حيث أنهم يقولون ادعاء الإرادة

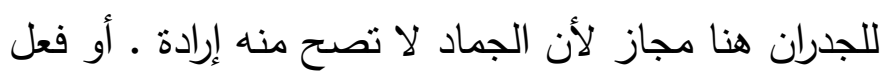

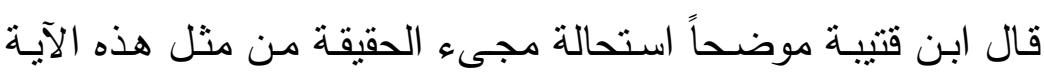

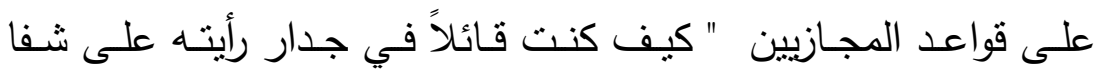
انهيار ؟ رأيت ماذا ؟ لم تجد بداً من أن تقول جداراً يهم أن ينقض أو يكاد 
أو يقارب..... وأيامـا قال فقد جعله فاعلاً . ولا أحسب يصل إلى هذا

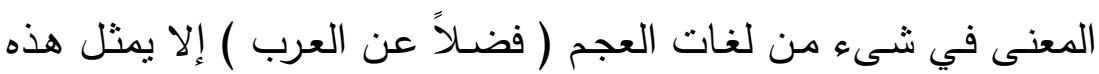

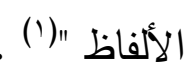

أيضاً من استحالة مجىء الحقيقة على حسب قواعدهم قولهم : كل

$$
\text { مجاز لا بد له من حقبقة ( في نهاية الأمر ) . }
$$

مثال : قالوا : قوللك : قطع الأمير اللص مجاز ، لأله الأن القطع قد يكون

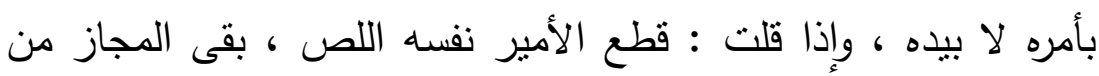

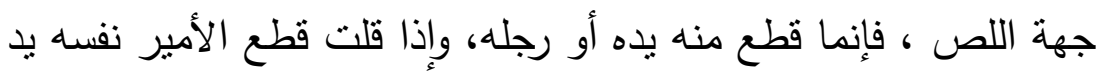

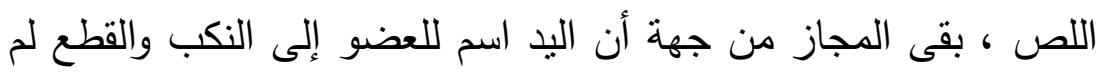

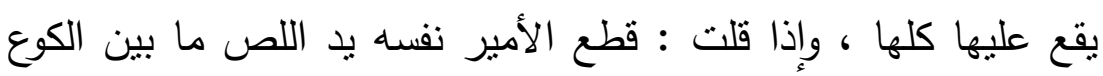

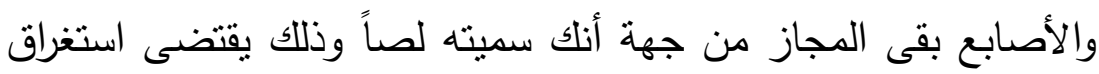

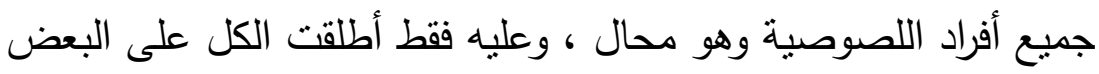

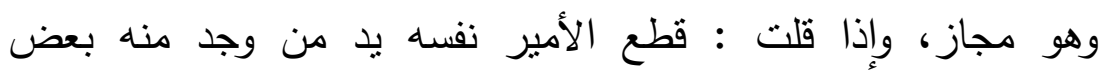

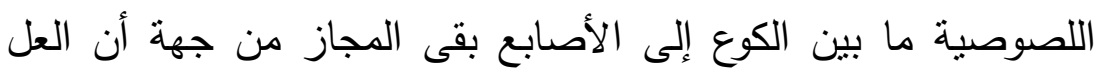

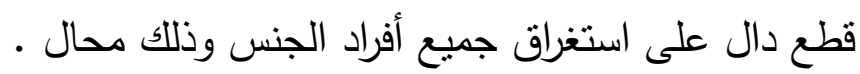
قالوا : فإذا أردت الحقيقة في هذه المسألة عليك أن تقول أنقال " أوقع الأمير نفسه فرداً من أفراد القطع على يد واحد ممن وجد منه بعض إضل فله

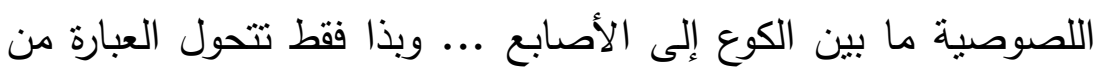

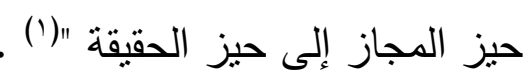

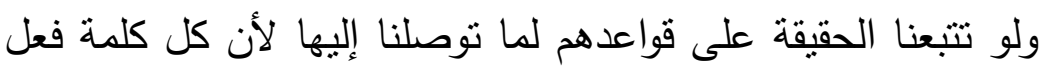
أو اسم يستغرق جميع الأجناس - على قولهم - وهذا الكلام لا طائل تحته بل هو من قبيل العبث . 
ويأبى اله أن يوفق عقل من يزعم أن غالب كلامه مجازاً لا حقيقة له

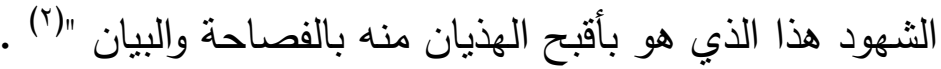

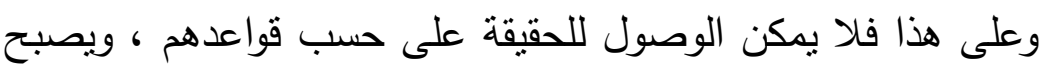
الكلام المستقيم الفصيح من الركاكة والغثاثة ما تمجه الآذان وتباه العقول

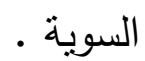

وما يرد عليهم الأصل الفاسد الذي أصله أحد كبار رؤوس المعتزلة ابن جنى فى مسألة المجاز حيث أدعى أن الفعل موضع لجميع أفراد المصدر، فإذا استعمل في بعضها كان مجازاً(") ) .

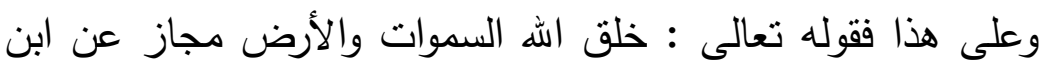

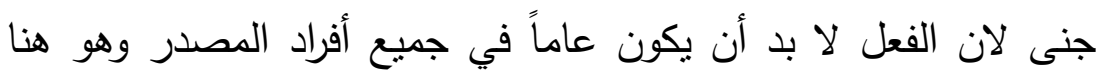

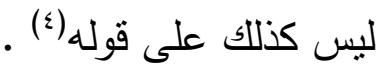
ولكن أقوالهم ينقض بعضها بعضاً فنجد من أصل هذا الأصل سرعان

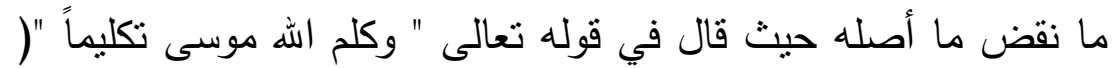

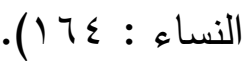

ليس هو من باب المجاز بل هو حقيقة ، فبقوله هذا نقض جميع ما بناه حيث قدم أن الفعل يقتضى جميع أفراد المصدر ، وأن الأفعال

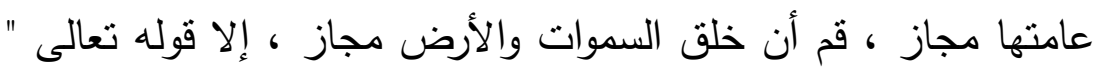
كلم الله موسى تكليماً " وحده حقيقة من سائر الأفعال (').

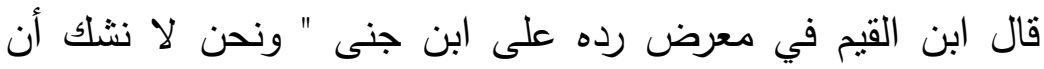

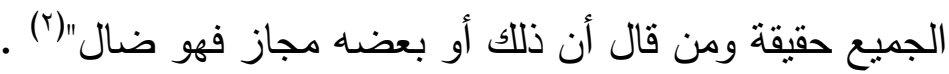

$$
\begin{aligned}
& \text { (Y) (Y) مختصر الصواعق :ص(Y)/ (Y) ). }
\end{aligned}
$$

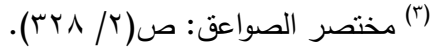

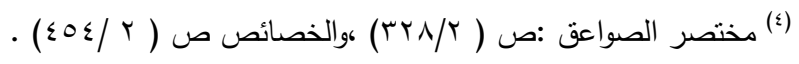

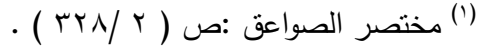

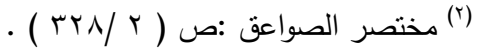


ومما يرد عليهم في قضية المجاز هو القول بأن الأصل حمل النص على الحقيقة والظاهر . فلا يصح حمل مدلول النص على خلاف حقيقته وظاهره إلا بأربعة

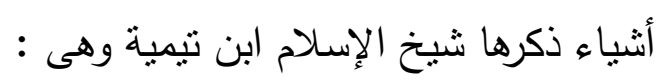

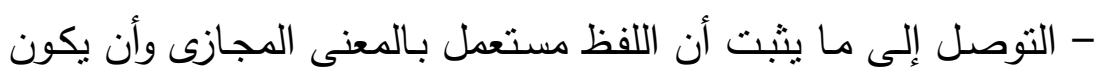
ذللك المعنى المدعى فيه المجاز لا يخل بالمعنى الثرعي للفظ ، وألا فيمكن لكل مبطل أن يفسد أى لفظ بأى معنى يسنح له وإن لم يكن له له بله

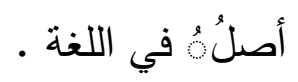

- دليل يوجب صرف اللفظ عن حقيقته إلى مجازه - أنه لا بد أن يسلم ذلك الدليل - الصارف - من معارض فإذا قام دليل

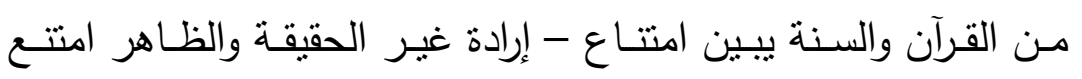
تركها . - أن الثارع إذا تكلم بكلام وأراد بـه خلاف ظاهره فلا بـ أن يبين للأمهـ ، لاسيما في الخطاب العلمي الذي أردا منهم فيه الاعتقاد(") .

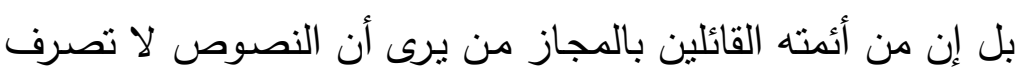

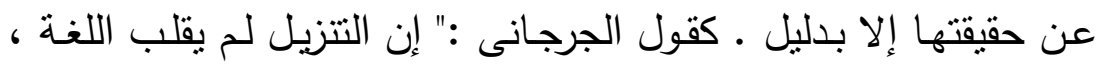

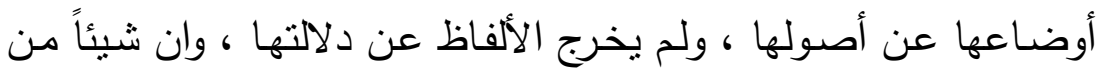

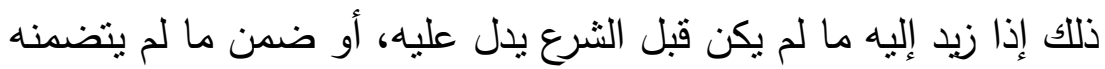
أتبع ببيان من عند النبي صلى الله عليه وسلم وذلك كبيانه للصلاة والحج

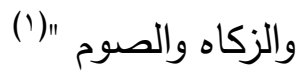
ولكن هل التزم المجازيون هذا القول - أو حتى نفس قائله الحال أنهم لم يلتزموا ذلك بل اتبعوا ما تمليه عليهم عقولهم وأهواؤهم . الفرق بين المجاز والتأويل

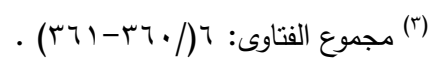

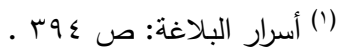


يرتبط المجاز بالتأويل ارتباطاً وثيقاً حتى إنه قد يلتبس أحياناً تمييز

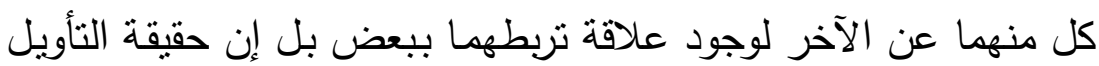

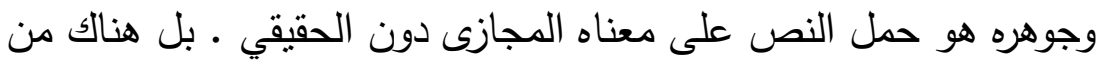

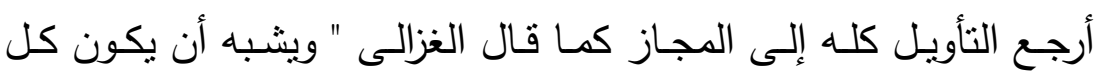

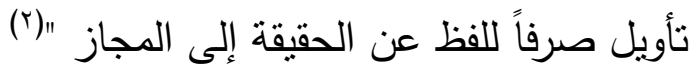
الهدف من ذلك الوصول إلى التميز بين التأويل والمجاز وإظهار الفرق بينهما . - المن وقد مر معنا تعريف كل من المجاز والتأويل حيث عرف المجاز

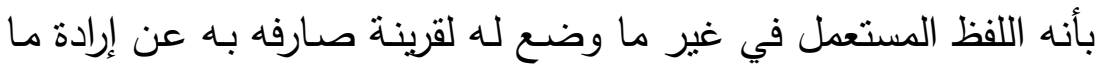
وضع له اللفظ، فالقرينة هى الصـارف عن الحقيقة إلى المجاز ، إذ اللفظ لا يدل على المعنى المجازى بنفسه دون قرينة . والتأويـل : هو صرف اللفظ من الاحتمـال الراجح إلى الاحتمال

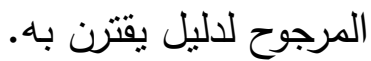
فبعد النظر في التعريفات السابقة لكل من المجاز والتأويل أتضـح التالي : كل من التأويل والمجاز ينطلق من الدلالة اللغوية للفظ ومع أنها ينطلقان من قاعدة لغوية أو بمعنى آخر ينطلقان من الاستعمال اللغوى،

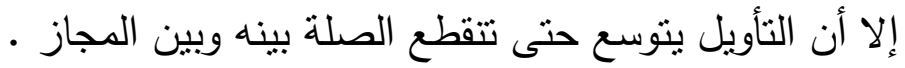

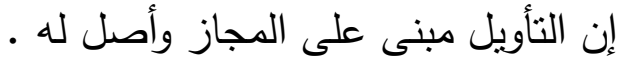

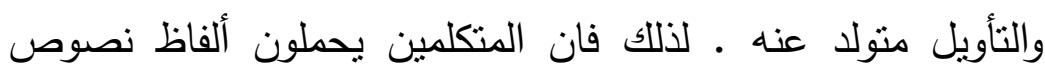
الصفات على المعاني المجازية التي يفرون بها عن التشبيه ويتركون

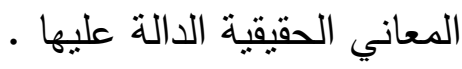
وتحرير المقال هنا أن المجاز أخف دلالة من التأويل

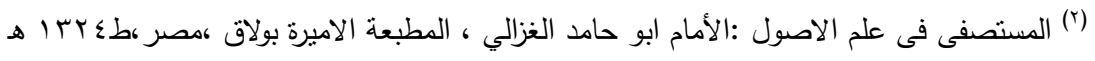

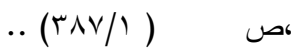




\section{بمعنى أن المجاز يظل استعمالاً لغوياً}

والتأويل يظل استعمالاً لغوياً عقدياً لأن المتكلمين أدخلوا المجاز في النياز التأويل فالتأويل والمجاز يندرجان تحت صرف اللفظ عن ما وضع له. أن المجاز نتأويل والتأويل مجاز لكن ليس كل تأويل يترتب عليه مجاز أما كل مجاز فيترتب عليه تأويل المجاز لله ضابطه والتأويل لا ضابط له له

فضابط المجاز اللغة ، فقد اثترط اللغويون القائلون بالمجاز أن

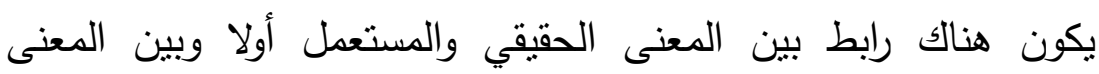

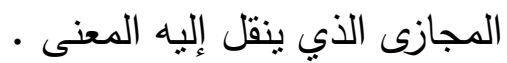

كما اشترطوا لصحة ذللك وجود قرينة تمنع من إرادة المعنى الحقيقي

فالقرينة في المجاز لا بد منها ، إذ هي الصارف عن الحقيقة إلى

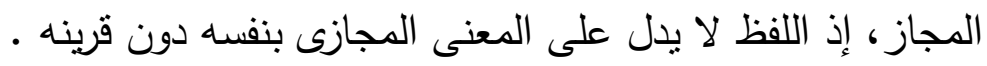

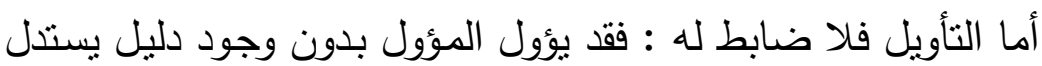

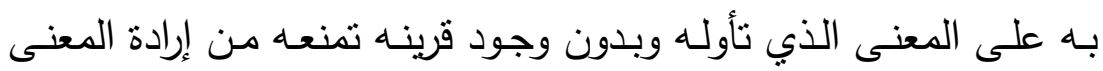

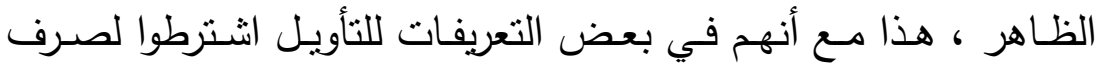
اللفظ عن ظاهره إلى معنى آخر وجود دليلي يقترن بـه، لكنهم لم يلتزموا

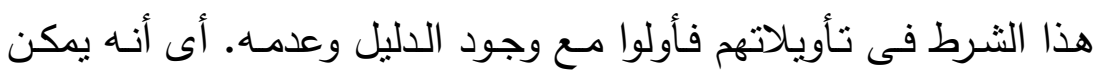
القول أن المجاز سلم للمتأول وأحد طرقه للتأويل. أى أن المجاز كان أولاً ثم يترتب عليه التأويل فباب المجاز كان أسبق وأوسع ثم التأويل بعد ذلك استعمل المبل المجاز وركبه للتعطيل. 
فالتأويل باب أوسع من المجاز من ناحية أخرى ومعانيه أكثر من

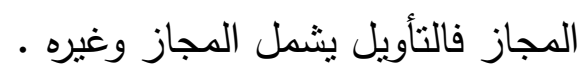

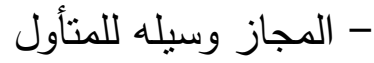
والتأويل عبارة عن نفس فعل المتأول وسئل التأويل والمجاز قد استعملا فى باب اصطلاحنى فعل عقى فقيها فساد كثير لما يترتب عليهما من تعطيل للأحكام الثرعيه التى يدل عليها النص.

ولو قارنا بين التأويل والمجاز عند المتكلمين والباطنية لوجد أن

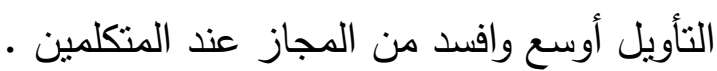

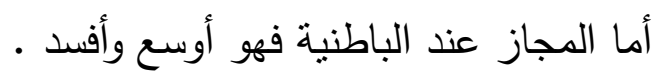
لأن المتكلمين : كان تعطيلهم ليس بهدف إفساد النصوص فالمتكلم المتأول المجازى مقصوده بالتأويل المجازى إزالة شبهة تعرض لهان أمامه فيحاول أن يدل على معنى بين وواضح بزعمه.

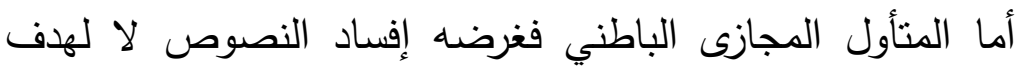
التبيين والإيضاح، وأحياناً يكون قد عرض عليه شبهة ولكن الأول أكد في حقه .

وبعد ، كلام من أجاز المجاز نوع من التطاول على الله إذ أن نتيجته

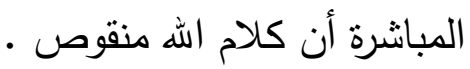
فباب المجاز من القضايا والمعالجات والأساليب الدخيلة على فقه انه

$$
\text { اللغة في التعامل الثرعى. }
$$

كما أتضح أن هناك صلة وثثية بين المجاز والتأويل حيث كل منهما يندمجان أحياناً للوصول إلى تعطيل نصوص الصفات وإنكار حقائقها 
وبعد النظر والتأمل في كل من المجاز والتأويل وجد أن ظهور

المجاز في النصوص الثرعية جاء نتيجة لنظر المتكلمين وتعاملهم مع هذه النصوص بعدم قبول ظواهرها ومعانيها التي يرون أنها توقع في التشبيه والتجسيح •

فحملوا ظواهرها على التأويل المجازى فهم يرون أن هذا الطريق هو طريق السلامة ، يقول الجرجانى :" ولو لم يجب البحث عن حقيقة المجاز ، والعناية به ، حتى تحصل ضروبه وتضبط أقسام ، إلا للسلامة

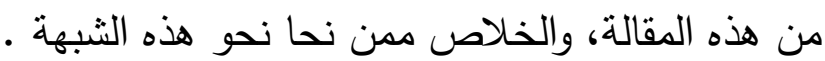
(أى إبقاء النصوص على ظواهرها ) لكان من حق العاقل أن يتوفر عليه ، ويصرف العناية اليه ، فكيف ويطالب الدين حاجة ماسة إليه من جهات يطول عدها ، وللثيطان من جانب الجهل به مداخل

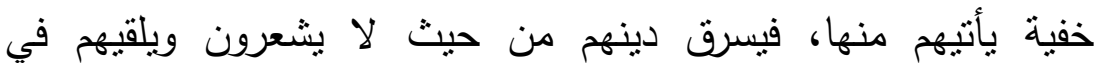

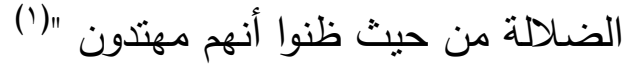
هذه هي نظرتهم للمجاز وانه المـلاذ المنجى من الوقوع في الثبهة هـه

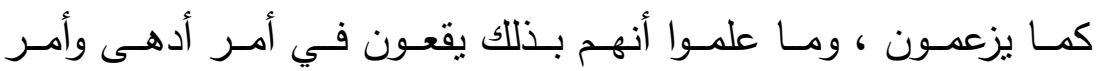

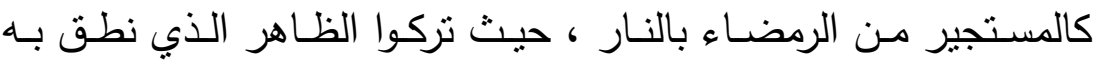

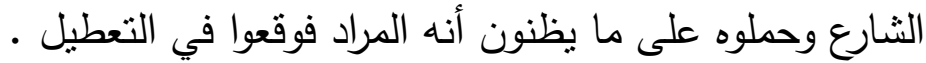

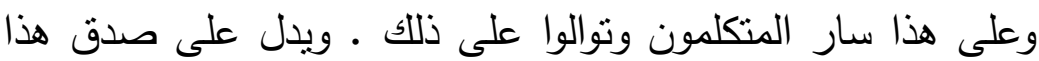

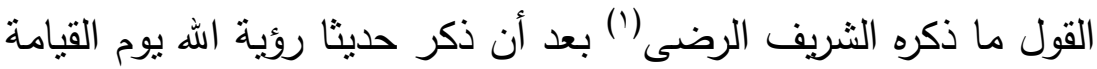
فقال :" وهذا الخبر مطعون في سنده، ولو صح نقله وسلم أصله لكان 
مجازاً من المجازات الني تحتاج إلى أن تحمل على التأويلات الموافقة

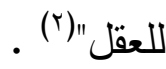

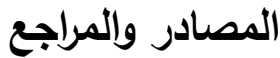

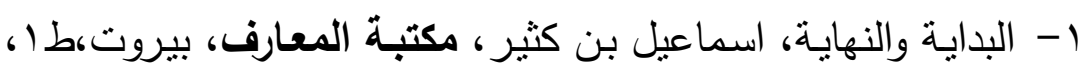

$$
\text { - } 1977
$$

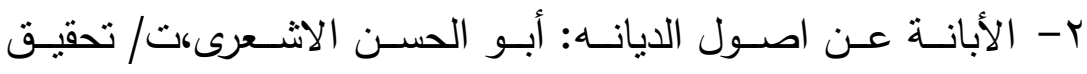

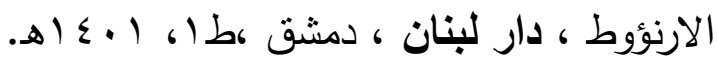

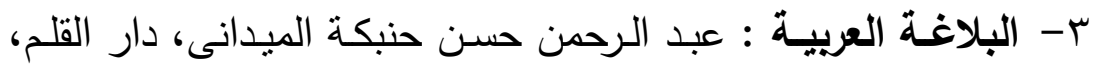

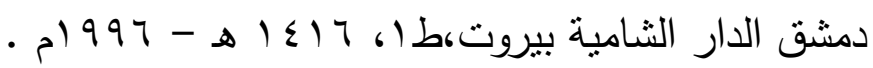




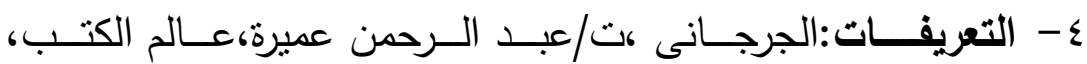

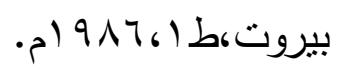

0- الرد على الجهمية والزنادقة مقدمة فى علم الكلام والمذاهب الهدامة

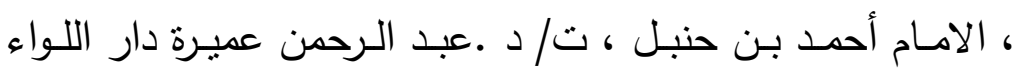

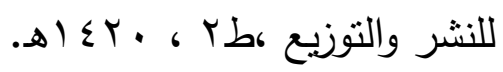

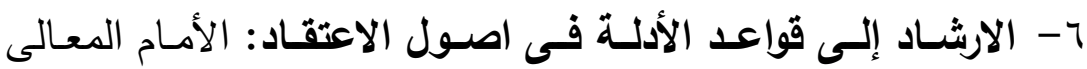

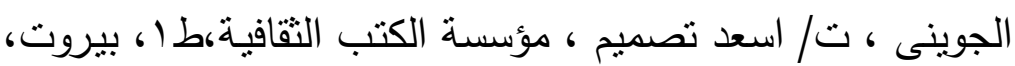

$$
\text { م) } 910-81 \leq 0
$$

V- الثامل فى اصول الدين:الأمام ابوالمعالي الجويني، وضـع حواشيه

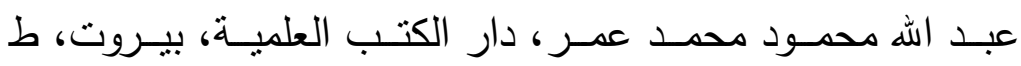

$$
\text { - م) } 999-81 \leq \cdot 1
$$

1- الطراز المتضمن لاسرار البلاغة وعلوم حقائق الاعجاز : يحيى بن

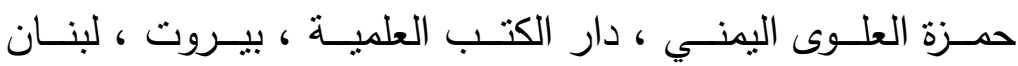

$$
\text { . } 191 \cdot-8 \mid \leq \ldots
$$

9- الفرق ببين الفرق :عبد القاهر بن طاهر البغدادى ، ت/د.محمد

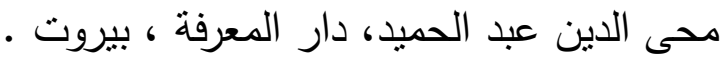

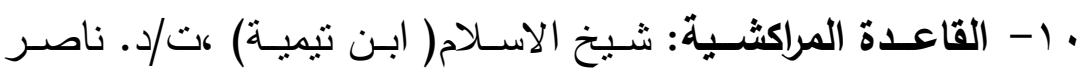

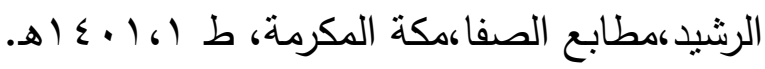
11- المستصفى فى علم الاصول :الأمام ابو حامد الغزالي ، المطبعة الهُ الاميرة كبولاق ،مصر ،طگ بس ا هـ .

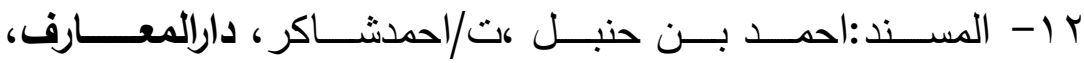

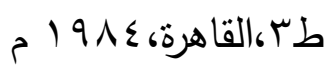

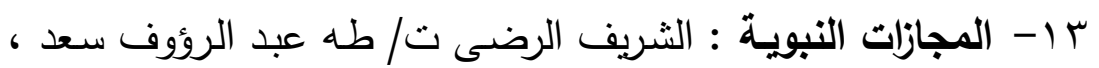
مطبعة الحلبي ، القاهرة اqجا هـ.

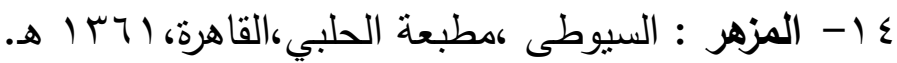




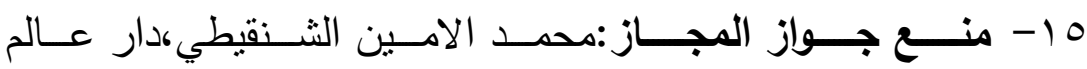

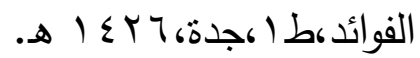

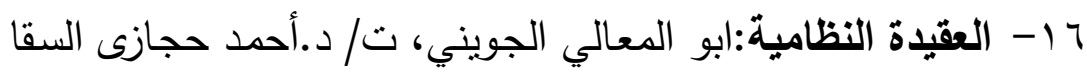

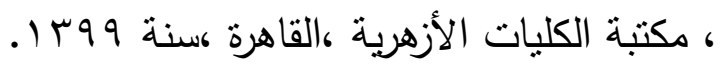

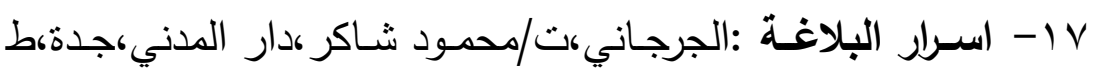
.

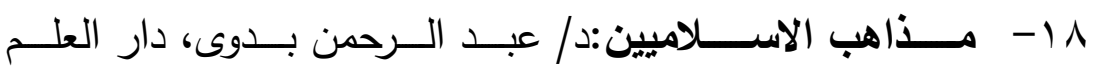

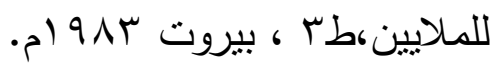

9 1 - لسـان العرب : ابن منظور جمال الدين محمد بن مكرم بن على بلى إنى الانصارى ، دار الصادر ، بيروت هVr آهـ ـ.

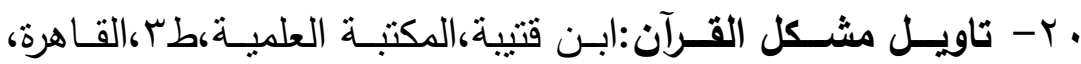
. ( ) 1

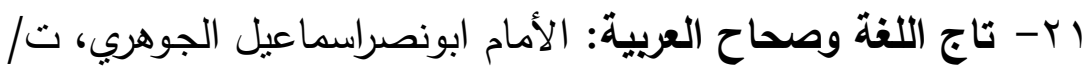

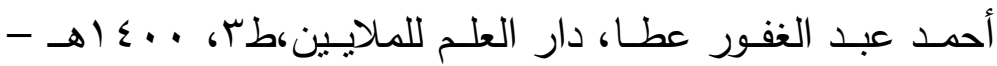

$$
\text { - ) } 9 \wedge 9
$$

ץ ب- تلخيص البيان فى مجـازات القرآن :الثريف الرضى، ت/محمد

عبد الغنى حسن ، دار احياء الكتب العربية ، القاهرة •90 أم ـ سץ- تنزيه القرآن عن المطاعن: القاضى عبد الجبار ، الثركة الثرقية للنشر والتوزيع، دار النهضة الحربية ، بيروت ، لبنان. ؟ ؟- تنزيه القرآن عن المطاعن: القاضى عبد الجبار ، الثركة الثرقية للنشر والتنوزيع، دار النهضة الحربية ، بيروت ، لبنان.

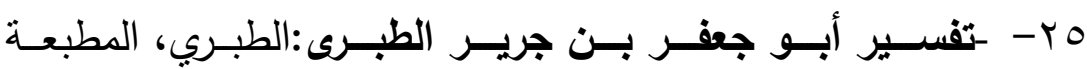

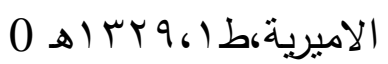

צr- رسالة أهل الثغر: أبو الحسن الاشعرى، ت / محمد السيد الجليند،

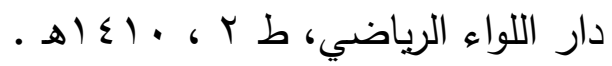




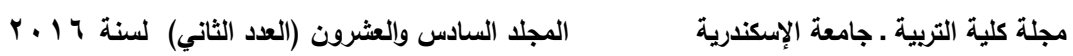

TV الألباني،مكتبة المعارف.

^ץ- سـنن الترمـذى :الترمذي،تات/احمد محمد شاكر ،مصطفي البابي

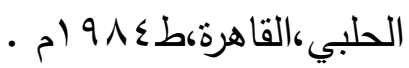

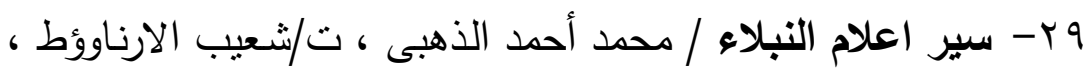

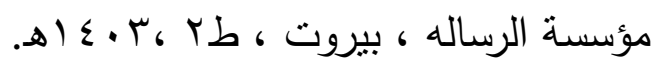

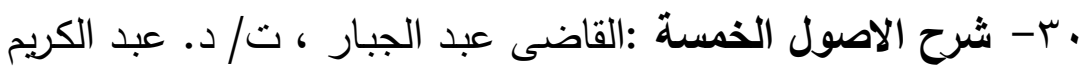

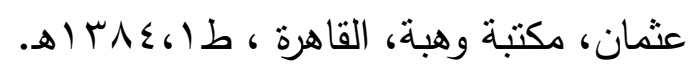

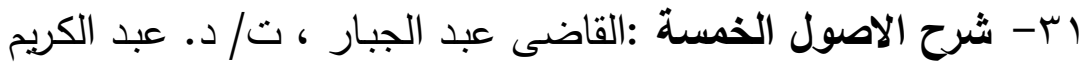

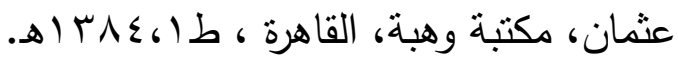

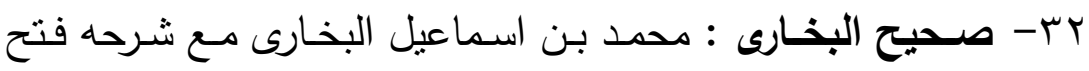

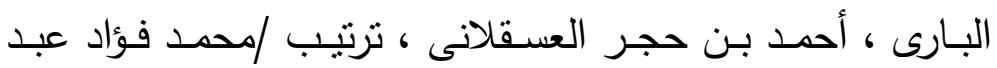

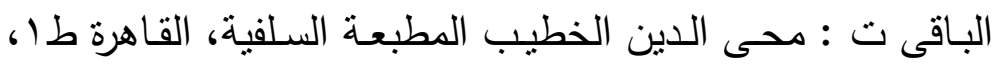

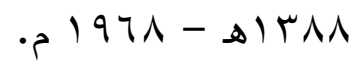

سب- صـحيح البخـارى: محمد بـن اسـماعيل البخـارى مـع شـرحه فتح

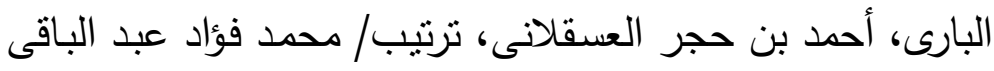

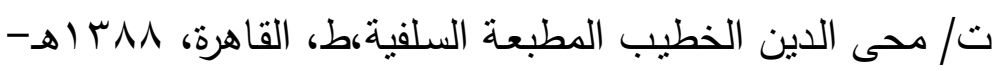
.01971

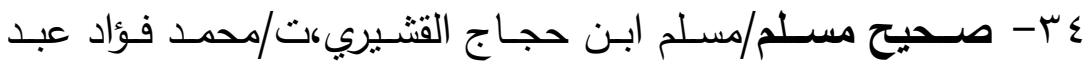

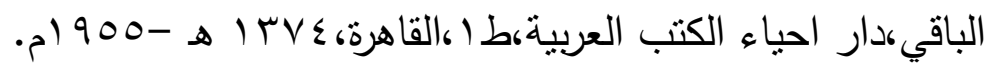
هـ- فلسفة المجاز بين البلاغة العربية والفكر الحديث: د/ لطفى عبد الداء

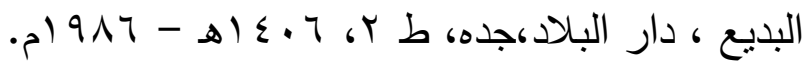


بس- مجمـوع الفتـــاوى:شـيخ الاســلام(ابن تيميـة)،جمع وترتيـب/ عبـد

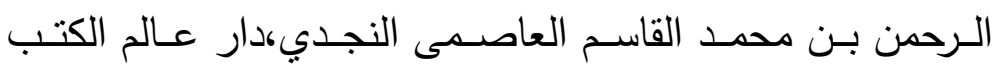

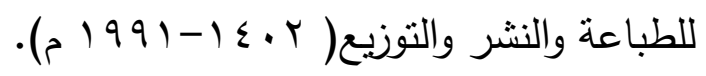

مجاز القرآن: أبو عبيدة معدر بن، علق عليه محمد فؤاد سركين

مكتبة الخانجى، مصر، بدون رقم الطبعة وتاريخها .

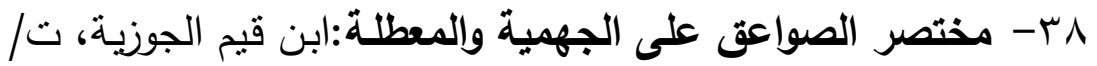

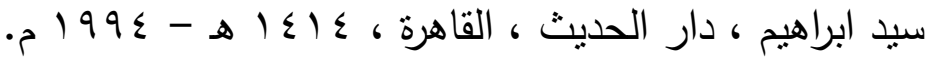

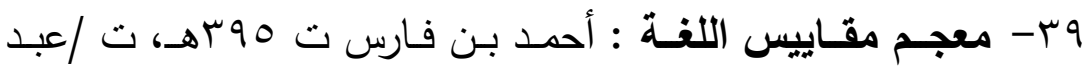

السـلام هـارون، طبع المجمع العلمى العربى الاسـامى، 99 بـ اهـ

$$
\text { - } 19 \vee 9-
$$

